\title{
COMMENTS
}

\section{THE GOAL OF THE NEW PREMERGER NOTIFICATION REQUIREMENTS: PRELIMINARY RELIEF AGAINST ANTICOMPETITIVE MERGERS}

The avowed purpose of the new premerger notification and waiting period requirements under section $7 \mathrm{a}$ of the Clayton Act $^{1}$ is to give the antitrust enforceinent agencies adequate information and time to seek preliminary relief prior to an anticompetitive merger or acquisition. ${ }^{2}$ Congress was unhappy with the results of the existmg notification program, as the Federal Trade Commission and the Justice Department had been unsuccessful in haltimg anticompetitive mergers prior to consummation. ${ }^{3}$ After completion of the inerger, divestiture was often an inadequate remedy: either the separation of merged assets was impractical after a period of protracted litigation, or the acquiring

THE FOLLOWING CITATIONS WILL BE USED IN THIS COMMENT:

The Antitrust Improvements Act of 1975: Hearings on S. 1284 Before the Subcomm. on Antitrust and Monopoly of the Senate Comm. on the Judiciary, 94th Cong., Ist \& 2d Sess. (1975-76) [hereinafter cited as Senate Hearings];

H.R. REP. No. 1373, 94th Cong., 2d Sess. (1976), reprinted in [I976] U.S. CODE CONG. \& AD. NEws 2637 [hereinafter cited as HOUSE REPORT];

L. SUlLivan, HANDBOOK OF THE LAW OF ANTITRUST (1977) [hereinafter cited as Sullivan];

Note, Preliminary Injunctions and the Enforcement of Section 7 of the Clayton Act, 40 N.Y.U.L. Rev. 771 (1965) [hereinafter cited as N.Y.U.L. REv. Note].

1. 15 U.S.C. \& 18a (1976). The regulations under the statute became effective on September 5, 1978. 43 Fed. Reg. 36,054 (1978). As of the end of 1978, 345 merger filings had been coinpleted, and the Justice Department, in cooperation with the Federal Trade Commission, was investigating 38 of these cases. Wall St. J., Dec. 29, 1978, at 4, col. 3.

2. House REPORT 5 ("H.R. I 4580 will . .. strengthen the enforcement of Section 7 by giving the government antitrust agencies a fair and reasonable opportunity to detect and investigate large inergers of questionable legality before they are consummated. The government will thus have a meaningful chance to win a premerger injunction").

3. Id. 8; Senate Hearings, pt. I, at 58 (introductory reinarks of Senator Hart); id. 76 (statement of Sen. Haskell) ("The present inerger review process simply does not work. The FTC and the Justice Department may not receive any notice of an impending merger"); id. 502-03 (stateinent of Joseph F. Brodley, Professor of Law, Indiana University) ("I have cited a study showing that in the period 1955-71, which is the big merger activity period, there were 167 merger snits and only 15 preliminary injunctions"). 
company had milked the acquired firm of technology, trade secrets, customers or liquidity during the imterim. ${ }^{4}$ In either case, restoration of the acquired firm as a viable competitor was impossible; the identities of the merging firms had become inextricably tangled. With Title II of the Hart-Scott-Rodimo Antitrust Improvements Act, ${ }^{5}$ Congress intended to cut this Gordian knot before it was tied by facilitating the procedural aspects of preliminary mjunctive rehef in antimerger cases. ${ }^{6}$

The standards governing preliminary relief agamst alleged antitrust violations are currently im a state of flux, as the federal courts have moved toward liberalization of the traditional standards controlling this type of equitable relief. Aware of the complexities imvolved in antitrust litigation, the courts of equity have generally sought to mamtain the status quo until final decision on the inerits. ${ }^{7}$ Although the courts have traditionally refused to issue preliminary injunctions without a showing that the government is likely to succeed at trial and that the balance of hardships favors the government, ${ }^{8}$ both these standards have been and are still being relaxed in antitrust cases. ${ }^{9}$ Further, the two standards, often held to be distinct and applied sequentially, are increasingly being melded, with the strength of the showing on one test affecting the showing required on the other. ${ }^{10}$

The purposes of this Comment are first, to show that the courts are moving away from traditional standards for preliminary injunctions in antitrust cases, with an identifiable trend toward an automatic approach in merger cases; and second, to discuss the influence of the new report-and-wait requirements in the courts and to examme the possible effects of the statute on the uncertain state of the law. The stakes are

4. HOUSE REPORT 8-10 ("During the course of the post-merger litigation, the acquired firm's assets, technology, marketing systems, and trademarks are replaced, transferred, sold off, or combined with those of the acquiring firn. Similarly, its personnel and management are shifted, retrained, or simply discharged"); Senate Hearings, pt. I, at 76 (statement of Sen. Haskell); id. 82 (statement of Thomas Kauper, Assistant Attorney General, Antitrust Division).

5. 15 U.S.C. § 18a (1976). The premerger notification measure was enacted as part of a compromise antitrust bill introduced by Senators Hart and Scott and Representative Rodino. Pub. L. No. 94-435, 90 Stat. 1383 (1976).

6. In addition to the bill's notification and waiting period requirements, 15 U.S.C. $\S 18 \mathrm{a}(\mathrm{(})(\mathrm{B})$ (1976) provides that the government's "motion for a preliminary injimction slall be set down for hearing by the district judge . . . at the earliest practicable time, shall take precedence over all matters except older matters of the same character and trials pursuant to section 3161 of Title 18, and shall be in every way expedited."

7. 2 P. AREeda \& D. TURner, ANTitrust LAw II 329, at 139 (1978); Schneiderinan, Preliminary Relief in Clayton Act Section 7 Cases, 42 ANTITrust L.J. 587, 587 (1973); Note, Civil Procedure-The Fourth Circuit's Liberal Approach to Preliminary Injunctions, 14 WAKE FOREST L. REv. 103, 114-16 (1977).

8. See Sullivan $\$ 215$, at 670 . See note 17 infra and text accompanying notes 13-17 infra.

9. See notes 18 \& 22 infra and text accompanying notes 7 supra and 18-26 infra.

10. See notes 18-22 infra and and accompanying text. 
high in antimerger litigation: granting preliminary relief may lead to abandonment of the merger; ${ }^{11}$ denying such relief may cause the plaintiff to drop the suit. ${ }^{12}$ The dollar values involved are often astronomical, and the potential impact of the new legislation is considerable.

\section{A BRoAdENING of EQuity's Traditions}

Courts liave traditionally been cautious in granting a remedy as drastic as the preliminary injunction. ${ }^{13}$ Under the traditional formula the plaintiff bears a heavy burden, as he must convince the court that

(1) there is a significant threat of irreparable harm to the plaintiff if the injunction is not granted;

(2) the plaintiff will probably succeed on the inerits;

(3) the balance between the irreparable harm to the plaintiff and the injury that granting the injunction would inflict on the defendant weighs in favor of the plaintiff; and

(4) the public interest favors granting the injunction. ${ }^{14}$

In Clayton Act suits brouglit by the government, the first requirement is ordinarily eliminated on the assumption that Congress, in authorizing the Justice Department and the Federal Trade Commission to seek preliminary injunctions, has determined that irreparable injury to the public will always result froin the proscribed anticompetitive conduct. ${ }^{15}$ By similar reasoning, the third and fourth requirements are fused into one in government suits: the test is one of balancing the public interest in preventing anticompetitive beliavior against the public and private

11. Mergers were abandoned after preliminary relief was granted in FTC v. Food Town Stores, Inc., 547 F.2d 247 (4th Cir. 1977); United States v. Ingersoll-Rand Co., 320 F.2d 509 (3d Cir. 1963); United States v. Allied Chen. Corp., 1964 Trade Cas. II 71,311 (S.D.N.Y. 1965); United States v. Chrysler Corp., 232 F. Supp. 651 (D.N.J. 1964). Sullivan \& 215, at 669 n.2. See Senate Hearings, pt. I, at 513 (statement of Professor Joseph F. Brodley); Lewis, Preliminary Injunctions in Government Section 7 Litigation, 17 ANTITRUST BULL. 1, 7 (1972); Schneiderman, supra note 7, at 598.

12. The government dropped its action after failing to obtain a preliminary imjunction in United States v. FMC Corp., 218 F. Supp. 817 (N.D. Cal.), appeal dismissed, 321 F.2d 534 (9th Cir.), application for preliminary injunction denied, 84 S. Ct. 4 (1963) (per Goldberg, J., in chambers) (not officially reported). SULLIVAN $\$ 215$, at 669 n.3.

13. 11 C. Wright \& A. Miller, Federal Practice and Proceddure, \& 2948, at 428-29 (1973).

14. Id. $\S 2948$, at $430-31$. Wright and Miller characterize these as the "four most important factors." Id. 430.

15. See, e.g., FTC v. Food Town Stores, Inc., 539 F.2d 1339 (4th Cir. 1976), vacated as moot, 547 F.2d 247 (4th Cir. 1977) (Food Town abandoned the merger prior to a hearing on the merits); United States v. Ingersoll-Rand Co., 320 F.2d 509 (3d Cir. 1963); United States. v. Atlantic Richfield Co., 297 F. Supp. 1061 (S.D.N.Y. 1969), affd sub nom. Bartlett v. United States, 401 U.S. 986 (1971); United States v. Wilson Sporting Goods Co., 288 F. Supp. 543 (N.D. Ill. 1968); United States v. Crocker-Anglo Nat'l Bank, 223 F. Supp. 849 (N.D. Cal. 1963); United States v. Aluminum Co. of America, 247 F. Supp. 308 (E.D. Mo. 1962), affd, 382 U.S. 12 (1965). See Developments in Law-Injunctions, 78 HARV. L. REv. 994, 1059 (1965). 
injury likely to result from the injunction. ${ }^{16}$ In weighing the equities, the courts inust also consider the adequacy of less drastic remedies. ${ }^{17}$ In suin, the test that the government must satisfy is twofold: it must demonstrate that it is likely to succeed on the merits at full hearing and that the balance of the equities is in its favor.

Over the past decade, the circuit courts have frequently departed from these traditional standards im antitrust cases, and current trends have generated some confusion as to the applicable standards. Perhaps in response to the critical commentary of those who favor an automatic approach, ${ }^{18}$ some courts have diluted the showing required of the government. The balancing test, developed primarily in the Second Circuit, sets an alternative standard for plaintiffs unable to show a likelihood of success on the merits. ${ }^{19}$ This test, requiring only that the plaintiff demonstrate "serious and substantial questions," has found favor in a inajority of the circuits-at least at the district court level. ${ }^{20}$ While tlie use of the "serious and substantial questions" test in private

16. See, e.g., FTC v. Atlantic Richfield Co., 549 F.2d 289 (4th Cir. 1977); FTC v. PepsiCo, Inc., 477 F.2d 24 (2d Cir. 1973); FTC v. Tenneco, Inc., 433 F. Supp. 105 (D.D.C. 1977); United States v. Wilson Sporting Goods Co., 288 F. Supp. 543 (N.D. Ill. 1968).

17. Such remedies include consolidation of the hearing on a preliminary injunction with trial on the nierits, hold-separate orders and divestiture. See note 159 infra and text accompanying notes 156-61 infra.

18. See SULLIVAN $\$ 215$, at 671 ("courts ought to be disposed to enter orders maintaining the status quo whenever the government offers by affidavits a colorable case that the inerger transcends legal standards and that adequate ultimate rehef would be jeopardized by allowing consummation"); Note, "Preliminary Preliminary" Relief Against Anticompetitive Mergers, 82 YALE L.J. 155,170 (1972). Legislative enaetments have also influenced courts to move toward an automatic approach. See, e.g., FTC v. Rhinechem Corp., 5 TRADE REg. REP. (CCH) \ 62,350, at 76,111 (N.D. Ill. 1978); FTC v. Lancaster Colony Corp., 434 F. Supp. 1088, 1097 (S.D.N.Y. 1977) ("Indeed, Section 13(b) [of the Federal Trade Commission Act] itself . . . reflects continuing congressional concern with the means of halting incipient violations of Clayton $\S 7$ before they occur').

19. See text accoinpanying notes 59-113 infra.

20. Courts adopting the balancing approach: Second Circuit: e.g., Sonesta Int'1 Hotels Corp. v. Wellington Assocs, 483 F.2d 247 (2d Cir. 1973); United States v. Culbro Corp., 436 F. Supp. 746 (S.D.N.Y. 1977); FTC v. Lancaster Colony Corp., 434 F. Supp. 1088 (S.D.N.Y. 1977). Third Circuit: e.g., Copperweld Corp. v. Inetal, 403 F. Supp. 579 (W.D. Pa. 1975); United States v. Pennzoil Co., 252 F. Supp. 962 (W.D. Pa. 1965). Fourth Circuit: Blackwelder Furniture Co. v. Seilig Mfg. Co., 550 F.2d 189 (4tlı Cir. 1977). Fifth Circuit: see Pearl Brewing Co. v. AnheuserBusch, Inc., 339 F. Supp. 945 (S.D. Tex. 1972). Sixth Circuit: Brandeis Mach. \& Supply Corp. v. Barber-Green Co., 503 F.2d 503 (6th Cir. 1974); see Beaute Craft Supply Co. v. Revlon, 402 F. Supp. 385 (E.D. Mich. 1975). Seventh Circuit: Mytinger \& Casselberry, Inc. v. Nummanna Laboratories Corp., 215 F.2d 382 (7th Cir. 1954); FTC v. Rhinechem Corp., 5 TRADE REG. REP. (CCH) I 62,350 (N.D. Ill. 1978); United States v. Parents Magazine Enterprises, Inc., 1962 Trade Cas. I 70,437 (N.D. Ill. 1962). Eighth Circuit: Paschall v. Kansas City Star Co., 441 F. Supp. 349 (W.D. Mo. 1977); United States v. Aluminum Co. of America, 247 F. Supp. 308 (E.D. Mo. 1964), affd, 382 U.S. 12 (1965). Ninth Circuit: e.g., William Inglis \& Sons Baking Co. v. I.T.T. Continental Baking Co., 526 F.2d 86 (9th Cir. 1975). Tenth Circuit: see Continental Oil Co. v. Frontier Ref. Co., 338 F.2d 780 (10th Cir. 1964). 
antitrust litigation dates back to the Harriman v. Northern Securities $\mathrm{Co}^{21}$ case, it has recently assumed increasing importance in antimerger suits initiated by the government. ${ }^{22}$ Further, the Fourth Circuit has recently adopted a rule prohibiting consideration of private hardship when weighing the equities. ${ }^{23}$ Any private losses defendant inight suffer as the result of a preliminary injunction issued under section 13(b) of the Federal Trade Commission $\mathrm{Act}^{24}$ are deemed irrelevant. The impact of this departure from equity's traditions is still uncertain: while many courts have required strong showings of extreme private hardship to outweigh the public interest in effective antitrust enforcement, ${ }^{25}$ no other appellate court has absolutely refused to consider private injury. ${ }^{26}$ In any event, conflicts have developed between the classic standards for a preliminary injunction and those set out in recent case law, and the federal courts are currently struggling to reconcile these differences.

Compounding the problems in the case law are the various statutory bases of jurisdiction under which the courts may grant preliminary relief. Section 15 of the Clayton Act authorizes the Justice Department to seek injunctions, ${ }^{27}$ section 16 authorizes the remedy for private plaintiffs. ${ }^{28}$ Until 1974, the Expeditimg Act of $1903^{29}$ further comphcated the jurisdictional scheme by providing that the Supreme Courtand not the courts of appeals-had jurisdiction on direct review of district court cases interpreting sections 15 and $16{ }^{30}$ Until 1966, the Federal Trade Commission (FTC) was not permitted to seek preliminary

21. 132 F. 464 (C.C.N.J. 1904), rev'd on the merits, 134 F. 331 (3d Cir. 1905).

22. No appellate court has yet adopted the lesser test in a government antimerger case. Recent apphications of the test in the Southern District of New York, see note 20 supra, raise the issue whether the serious and substantial questions test should be apphed in government actions. See text accoinpanying notes 162-65 infra.

23. FTC v. Food Town Stores, Inc., 539 F.2d 1339 (4th Cir. 1976), vacated as moot, 547 F.2d 247 (4th Cir. 1977).

24. 15 U.S.C. $\$ 53(b)(1976)$.

25. See text accoinpanying notes $134-42$ infra.

26. But see FTC v. Lancaster Colony Corp., 434 F. Supp. 1088, 1096 (S.D.N.Y. 1977) (citing with approval FTC v. Food Town Stores, Inc., 539 F.2d 1339 (4th Cir. 1976), vacated as moot, 547 F.2d 247 (4th Cir. 1977)).

27. 15 U.S.C. $\$ 25$ (1976).

28. Id. $\$ 26$.

29. Act of Feb. 11, 1903, ch. 544, 32 Stat. 823.

30. United States v. FMC Corp., 84 S. Ct. 4 (1963) (per Goldberg, J., in chambers) (not officially reported). Direct appeal is now available only from final judgments in government antitrust suits seeking equitable rehef where, on application of a party, the district court issues an expediting order and the Supreme Court elects to hear the case rather than to remand to the court of appeals. 15 U.S.C. $\$ 29$ (1976). See generally C. WRIGHT, LAW OF THE FEDERAL CourTS $\S 105$, at 527-28 (3d ed. 1976). 
imjunctions from the courts; ${ }^{31}$ eventually the Supreme Court, in FTC $v$. Dean Foods Co. ${ }^{32}$ found the necessary jurisdiction for the appellate courts under the All Writs Act. ${ }^{33}$ Shightly different standards control under each of these jurisdictional statutes. ${ }^{34}$ The most serious problem of jurisdiction, however, mvolves an annendment to the Federal Trade Commission Act, adding section 13(b), ${ }^{35}$ which authorizes the FTC to seek prelinmary injunctions in the district courts to restrain violations of any law that it enforces. ${ }^{36}$ Distimctions between the language of Clayton Act section 15 and that of Federal Trade Commission Act section 13(b) apparently make section 13(b) a more favorable jurisdictional ground for the government. ${ }^{37}$ There has been some doubt whether traditional equity standards apply at all under that anendment. ${ }^{38}$ Tliese doubts and differences create further conflict annong the courts and lead to anoinalous results in strikingly similar government actions. ${ }^{39}$

31. See, e.g., FTC v. International Paper Co., 241 F.2d 372 (2d Cir. 1956).

32. 384 U.S. 597 (1966).

33. 28 U.S.C. \& 165(a) (1970). The holding became obsolete when Congress enacted 15 U.S.C. \& 53(b) (1976), giving the FTC specific statutory power to seek such injunctions.

34. Under Clayton Act $\S 16,15$ U.S.C. $§ 26$ (1976), the private plaintiff inust show immediate danger of irreparable harm, e.g., Triebwasser \& Katz v. A.T. \& T. Co., 535 F.2d 1356, 1359 (2d Cir. 1976), whereas the language of Clayton Act $\S 15,15$ U.S.C. $\$ 25$ (1976), eliminates that requirement in government suits, e.g., United States v. Atlantic Richfield Co., 297 F. Supp. 1061, 1074 n.21 (S.D.N.Y. 1969), aff'd sub nom. Bartlett v. United States, 401 U.S. 986 (1971). The Dean Foods holding under the All Writs Act, on the other hand, was interpreted to require that the FTC show that "an effective remedial order, once the nerger was implemented, would . . . be virtually impossible" if the injunetion were denied. FTC v. PepsiCo, Inc., 477 F.2d 24, 28-29 (2d Cir. 1973).

35. Sec note 18 supra.

36. 15 U.S.C. \& 53(b) (1976) provides:

Whenever the Commission has reason to behieve-

(1) that any person, partnership, or corporation is violating, or is about to violate, any provision of law enforced by the Federal Trade Commission, and

(2) that the enjoining thereof pending the issuance of a complaint by the Cornmission and until such complaint is dismissed by the Commission or set aside by the court on review, or until the order of the Commission inade thereon has become final, would be in the interest of the publie-

the Commission . . . nuay bring suit in a district court of the United States to enjoin any such act or practice. Upon a proper showing that, weighing the equities and considering the Commission's likelihood of ultimate success, such action would be in the public interest,. . . . a preliminary injunction may be granted without bond . . . .

(Einphasis added.)

37. Section 13(b) has been held to preclude the weighing of private equities, although similar provisions of the Clayton Act are subject to no such interpretation. See notes 120, 127, 132 infra and text accompanying notes 114-32 infra. See Annot., 34 A.L.R. FED. 507 (1977). (1951).

38. Interpretation of a very similar provision, § 13(a), is discussed at 65 HARV. L. REv. 349

39. Compare FTC v. PepsiCo, Inc., 477 F.2d 24 (2d Cir. 1973) (injunction denied under All Writs Act) with FTC v. Lancaster Colony Corp., 434 F. Supp. 1088 (S.D.N.Y. 1977) (injunction 


\section{The New Statute's Impact on Current Law}

The notification statute is intended to change only the procedural aspects of antitrust litigation; it is not designed to alter substantive standards, nor to set up any hard and fast rules governing the propriety of injunctive relief..$^{40}$ Thus, the statute does not address directly the substantive problems the courts are now facmg. The premerger legislation will, however, lave some substantive impact on the government's ability to obtain a preliminary injunction in a particular case. On the merits, the enforcement agencies' access to all relevant information weeks prior to the merger will clearly aid im preparation for the showing of a likelihood of success. ${ }^{41}$ The statute's legislative history, with its emphasis on the inadequacy of divestiture to protect the public interest in effective antitrust enforcement, ${ }^{42}$ may influence the courts to favor the government's case on the equities. ${ }^{43}$ The idea that divestiture is an unsatisfactory remedy is hardly new, ${ }^{44}$ but it was a recurrent theme throughout the Senate hearings and the smgle most important motive for the legislation. ${ }^{45}$ Under this analysis, the issuance of a preliminary injunction would become virtually automatic, especially if the courts

granted under 15 U.S.C. $\$$ 53(b)) and United States v. Culbro Corp., 436 F. Supp. 746 (S.D.N.Y. 1977) (injunction denied under 15 U.S.C. $\$ 15$ ).

40. HousE REPORT 8 . The statute is also unlikely to stall the current merger wave. National L.J., Oct. 30, 1978, at 6, col. 2.

41. See text accompanying notes 170-93 infra. Senate Hearings, pt. I, 71 (statement of Lewis Engman, Chairman, FTC) ("if we can get information to support our position, we can go to court and obtain an order that ensures that there will be a divestible entity if we ultimately prevail. . . The . . . waiting period will permit us . . to obtain information and to seek appropriate relief'); id. 90, 96 (statement of Thomas Kauper, Assistant Attorney General, Antitrust Division); Sullivan $\$ 215$, at $669 \mathrm{n.l}$ ("This act, passed as a compromise measure, would facilitate pre-merger investigation and greatly enhance the potential for preliminary relief').

42. See note 4 supra. Similar statements are found in Senate Hearings, pt. I, 205 (statement of Professor Walter Adams, Michigan State University) ("This . . . provision . . . would avoid the practical difficulties of a postmerger unscrambling of already commingled assets, or of convincing the courts to undertake this onerous task"); id., pt. II, at 535, 546 (statement of John Flynn) ("the economic incentives of reaping the profits of the merger in the form of dividends and capital gains inake ultimate divestiture a loug and tedious process"); id. 584 (letter from Consumer Protection Board, Executive Department, State of New York). Additional problems are involved in partial divestiture, the handling of improvements and locating a buyer who is not in coinpetition with the divested firm. Elzinga, The Antimerger Law: Pyrrhic Victories?, 12 J.L. \& ECON. 43, 53-74 (1969).

43. Cf. FTC v. Lancaster Colony Corp., 434 F. Supp. 1088 (S.D.N.Y. 1977) ("The legislative history of Section 13(b) reveals congressional concern with the FTC's historic inability to effectuate a remedy once an acquisition is consummated. . . . [The provision] shows congressional recognition of the fact that divestiture is an inadequate and unsatisfactory remedy . . . " The court concluded that no evidentiary hearing or extensive analysis of the underlying antitrust issues was necessary where a Clayton $\$ 7$ violation was alleged). See text accompanying notes 201-213 infra.

44. See Elzinga, supra note 42.

45. See notes $4 \& 42$ supra. 
continue their current trend toward liberalization of equity's standards.

In light of the legislative history, however, the courts must avoid any radical departure from equity's traditions. The Senate did consider including a provision for automatic relief in the legislation; the bill as originally proposed would have given the enforcenent agencies a preliminary injunction solely on certification to the district court that the public interest required such relief pendente lite. ${ }^{46}$ Heavy opposition to this provision came from almost every quarter. Both the Chairman of the Federal Trade Commission and the Assistant Attorney General for the Antitrust Division rejected the proposal in Senate hearings, advising that such discretionary power would be unnecessarily broad. ${ }^{47}$ Assistant Attorney General Kauper's remarks were representative of the agencies' attitude: 'I suppose, like many bureaucrats, it is nice to have power, but I am also a little suspicious of it, and I think that perliaps that [automatic-stay provision] goes somewhat too far."48 The business community vigorousiy opposed the autonatic injunction, witl one business representative attacking the legislation as a denial of due process. ${ }^{49}$ Even witnesses who supported the provision expressed concern about possible chilling effects on lawful merger activity. ${ }^{50}$ If anything emerges clearly from the Senate hearings on its Title V legislation, ${ }^{51}$ it is the almost uniform criticisin of the attempt to deprive the courts of their discretion on inerger injunctions. Congressional debate, showing further hostility to such legislation, indicates that the proposal was dooined from the outset. ${ }^{52}$

Two considerations in addition to fear of bureaucratic overreaching support the legislature's decision to omit any automatic-stay provision from the statute. The first is the value of tradition in federal jurisprudence. The Supreme Court has addressed the issue with eloquence:

We are dealing here with the requirements of equity practice with a background of several hundred years of history. . . . Flexibility rather than rigidity has distinguished it. The qualities of mercy and practicality have made equity the instrument for nice adjustment and reconciliation between the public interest and private needs as well

46. S. 1284, 94th Cong., 1st Sess. § 23(d) (1975), reprinted in Senate Hearings, pt. I, at 29-30.

47. Senate Hearings, pt. I, at 71,82 .

48. Id. 82.

49. Id. 195 (statements on S. 1284, Antitrust and FTC Act Amendments, for the Chamber of Commerce of the United States by J.W. Riehm and J. Randolph Wilson).

50. Id. 513 (statement of Professor Joseph F. Brodley).

51. The premerger notification requirements were set out in Title $V$ of the Senate bill but were included in Title II of the House bill. See note 5 supra.

52. 122 Cong. Rec. S15,420 (daily ed. Sept. 8, 1976) (remarks of Senator Percy). 
as between competing private claims. ${ }^{53}$

Tradition is basic to the concept of equity and prevents conflict or confusion among the lower courts. The second consideration, emphasized throughout hearings on the notification statute, is the necessity for liquidity im the capital assets market. ${ }^{54}$ To delay a merger is often to kill the merger, and witnesses expressed doubt that entrepreneurial activity could coexist with that degree of governmental control implicit in the automatic stay. ${ }^{55}$ The legislature foresaw that such an amendment to the antitrust laws could in fact harin competition by preventing mergers that would be in the public interest. ${ }^{56}$ Congress was unwilling to give the FTC and the Justice Department the power to forestall any merger they thought undesirable; the legislature left the decision to the courts of equity $\mathrm{m}$ their traditional discretion.

\section{The Development of Modern Approaches}

In the legislative history of the notification statute, Congress expressed great concern for the broad policy issues involved in preliminary rehef against challenged inergers but directed hittle if any attention to recent developments in the federal courts. In the hearings and debates, Congress ignored both the Second Circuit's balancing approach $^{57}$ and the Fourth Circuit's refusal to consider private imjury im section 13(b) actions. ${ }^{58}$ These developments, however, are of great significance in government antimerger suits, and it is therefore necessary to examine the origin of these tests and their impact on federal equityparticularly in hight of the concerns expressed before the legislature in formulating the Clayton Act amendments.

\section{A. The Probability of Success: The Second Circuit's Substantial Questions Test.}

Traditionally, the two requirements for issuance of a preliminary mjunction have been apphed sequentially; that is, the courts have first required proof of a reasonable probability of success at plenary hearings and have then proceeded to weigh the equities. ${ }^{59}$ The balancing

53. Hecht Co. v. Bowels, 321 U.S. 321, 329-30 (1944).

54. Senate Hearings, pt. I, at 157 (statement of J. Randolph Wilson on behalf of the U.S. Chamber of Commerce); id. 513 (statement of Professor Joseph F. Brodley); id. 529-30 (statement of Robert A. Longman, Chairman, Antitrust Section, New York State Bar Association); id., pt. II, at 1033 (memorandum from the Securities Industry Association).

55. See text accompanying note 54 supra.

56. CoNG. ReC., supra note 52.

57. See text accompanying notes 59-113 infra.

58. See text accompanying notes 114-65 infra.

59. See Metzger \& Friedlander, The Preliminary Injunction: Injury Without Remedy?, 29 Bus. 
approach, however, represents an exception to this rule: the equities are weighed first, and where they balance decidedly in favor of the moving party, the injunction will issue merely on a showing of serious and substantial questions on the merits. ${ }^{60}$ In other words, a strong showing on the equities inay offset a weak showing on the inerits. The impact of the balancing approach on federal equity practice has been substantial-the exception may soon engulf the rule in antitrust cases. ${ }^{61}$

Despite broad acceptance of the balancing approach, the test, as it is currently applied, is subject to three major criticisms. First, the modern version of the approach is arguably a bastardization of equity's traditional role in pretecting and reconciling competing claims. ${ }^{62}$ Second, to the extent that the modern rule represents a departure from tradition, it has led to confusion among the courts and to attempts to retreat from its nore liberal tests. ${ }^{63}$ Third, the true function of the approach in antitrust cases nay be primarily to satisfy the courts' desire to postpone consideration of complex substantive issues until full hearing, ${ }^{64}$ a goal which is particularly mappropriate where issuance of the injunction will probably mean the abandonment of merger plans. A brief history and analysis of the case law serves to illustrate these weaknesses.

In order to measure the extent to which modern law has departed from traditional equity practice, it is necessary to look back to the turn of the century. The balancing approach originated in and was developed primarily by the Second Circuit, where its application in antimerger suits began with Harriman v. Northern Securities Co ${ }^{65}$ In that case, the old circuit court sitting in New Jersey granted preliminary relief despite Harriman's failure to show a likelihood of success on the

LAw. 913, 915 (1974) ("The [four] rules of Virginia Petroleum [Jobbers Ass'n v. FPC, 259 F.2d 291 (D.C. Cir. 1958)] have been viewed by the courts as sequential in concept as well as expression. That is, a petitioner must first deinonstrate a probability of ultimate success before the courts will even consider the irreparable imjury question" (footnotes omitted)).

60. The courts use various phrases to describe the requirement of probable success on the merits, but there is little substantive difference between one wording and another. 11 WRIGHT \& MILLER, supra note 13, at 451-52. Courts have long acknowledged, however, a substantive difference between requiring a probability of success and requiring only serious and substantial questions. See cases cited in note 66 infra and see accompanying text. For example, the holding in Copperweld Corp. v. Imetal, 403 F. Supp. 579 (W.D. Pa. 1975), apparently hinged on this very distimction. Also see Chemetron Corp. v. Crane Co., 1977-2 Trade Cas. I 6I,717 (N.D. Ill. 1977), where the court rejected the liberal balancing test. See Note, supra note 7, at 109-10.

61. See note 20 supra for a selective list of those courts adopting the balancing approach.

62. See note 74 infra and text accompanying notes 65-74 infra.

63. See notes 87 \& 89 infra and text accompanying notes $84-90$ infra.

64. See text accompanying notes 91-95 infra. See N.Y.U.L. REv. Note at 776 (balancing approach turns on complexity of issues raised rather than on strength of plaimtiffs case).

65. 132 F. 464 (C.C.N.J. 1904), rev'd on the merits, 134 F. 331 (3d Cir. 1905). 
merits. The court cited a long line of cases, both American and Enghish, ${ }^{66}$ in support of a rather narrow exception to the usual requirement of a showing of probable success on the merits. Where the moving party would suffer "immediate, certam and great"67 injury if the court denied the injunction and where harm to the defendant would be " $\mathrm{m}$ considerable"68 if the court granted it, a preliminary injunction would issue on a showing of only substantial questions on the merits. ${ }^{69}$ Only an "enormous preponderance of mconvemence"70 to plaintiff would warrant the exception. The court set out its rationale: "The balance of convemence or hardship . . . is a factor of controlling importance in cases of substantial doubt existing at the time of grantimg or refusing a preliminary injunction."71 The narrow exception set out here seeins firmly within equity's traditions and is based on a strong and well-reasoned line of precedent.

The inajor departure from this statement of the rule appeared in Hamilton Watch Co. v. Benrus Watch Co. ${ }^{72}$ involving a Clayton Act challenge brought by the target of an unfriendly takeover. In affirming the district court's preliminary injunction, Judge Frank also placed particular einphasis on the balance of hardship:

To justify a temporary injunction it is not necessary that the plaintiff's right to a final decision, after a trial, be absolutely certain. ...; if the other elements are present (i.e., the balance of hardships tips decidedly toward plaintiff), it will ordimarily be enough that the plaintiff has raised questions going to the inerits so serious, substantial, difficult and doubtful, as to make then a fair ground for hitigation and thus for inore deliberate investigation. ${ }^{73}$

Frank's language - “tips decidedly toward plaimtiff"-is a markedly liberal version of the standard set out im Northern Securities. The parenthetical language of Hamilton Watch may be merely a casual restatement of precedent; the court did not ultimately decide the case on the issue of probability of success. The federal courts, nonetheless, have adopted the Hamilton Watch wording, and the narrow exception to the probability of success requirement has consequently become signifi-

66. Among the cases cited were Allison v. Corson, 88 F. 851 (8th Cir. 1898); City of Newton v. Levis, 79 F. 715 (8th Cir. 1897); Shrewsbury \& Chester v. Shrewsbury \& Birmingham Ry., [1851] 1 Sim. (n.s.) 410, reprinted in 61 Eng. Rep. 159 (V.C. 1851).

67. 132 F. at 485 (quoting Denver \& Rio Grande R.R. v. United States, 124 F. 156, 161 (8th Cir. 1903)).

68. 132 F. at 476 (quoting City of Newton v. Levis, 79 F. 715, 718 (8th Cir. 1897)).

69. 132 F. at 485.

70. Id. at 478 (quoting Shrewsbury \& Chester v. Shrewsbury \& Birmingham Ry., [1851] 1 Sim. (n.s.) 410, 434, reprinted in 61 Eng. Rep. 159, 168 (V.C. 1851)).

71. 132 F. at 476 .

72. 206 F.2d 738 (2d Cir. 1953).

73. Id. at 740 (footnote ornitted). 
cantly broader. ${ }^{74}$

Frank's unorthodox statement of the rule did not meet with immediate acceptance throughout the federal courts. The district court in United States v. Brown Shoe Co. ${ }^{75}$ one of the first government cases to consider Hamilton Watch, acknowledged the Eighth Circuit's line of holdings similar to that in Northern Securities ${ }^{7}$ but rejected Frank's language. The court distimguished Hamilton Watch on the ground that the Brown Shoe case was "not the 'ordmary case' where proof to support issuance of the writ in the 'ordmary' case should apply."77 This distinction may seem somewhat superficial, but the reasons for the court's hesitation are clear:

Taken literally, the requirements for issuance of a preliminary writ are very meager. We are reluctant to believe the Government would institute proceedings that did not present at least a "fair ground for litigation" and "deliberate investigation" by the Court, because issues are "serious, substantial and doubtful." Few Clayton Act cases are simple. Seldoin is the Court without doubt in its decision even though it does not say so. The Hamilton Watch case does not hold that the quantum of proof indicated shall apply in all cases-"it will ordinarily be enough."

The Hamilton Watch rule, while supported by precedent, clearly went beyond the traditional exception, and the court in Brown Shoe was unwilling to accept the liberal standard.

More recently, the rule of Hamilton Watch has become firmly entrenched in the Second Circuit. The rule reached its maturity in

74. The Hamilton Watch decision did not address the showing necessary to tip the balance decidedly in favor of the moving party, but it is clear that the government is not required to make the traditioual showing of an "enormous preponderance of inconvenience." As the court stated in Paschall v. Kansas City Star Co., 5 TRADE REg. REP. (CCH) I 62,261 at 75,631 (W.D. Mo. 1977), the Northern Securities test has "been variously expressed, and, recently, [has] been applied in such a manner as to minimize the iniportance of the movants showing a likelihood of success on the merits." Id. at 356. In fact, the courts have sometimes allowed the substantial questious test and shifted the burden on the equities to the defendant. E.g., United States v. Pennzoil Co., 252 F. Supp. 962, 986 (W.D. Pa. 1965). See FTC v. Rhinechenı Corp., 5 TRADE Reg. ReP. (CCH) If 62,350, at 76,113 (N.D. Ill. 1978); FTC v. Lancaster Colony Corp., 434 F. Supp. 1088 (S.D.N.Y. 1977). Since the Hamilion Walch standard requires no examination of the strength of plaintiff's case, the Pennzoil approach requires only that the government present coniplex issues-a very ineager requirement in antitrust cases. See N.Y.U.L. REv. Note 776 (citing United States v. Aluminum Corp. of Anierica, 214 F. Supp. 501 (N.D.N.Y. 1963), rev'd, 377 U.S. 271 (1964), as a case in which the liberal Hamilton Watch rule led to a questionable decision).

75. 1956 Trade Cas. \68,244, at 71,109 (E.D. Mo. 1956). Although never officially reported, Judge Hulen's memorandum opinion is reprinted in part in further proceedings growing out of the saine merger. 179 F. Supp. 721,724 n.4 (E.D. Mo. 1959), aff'd, 370 U.S. 294 (1962).

76. 1956 Trade Cas. at 71,114 .

77. Id. at 71,116 .

78. Id. at 71,115 (emphasis in original). The Eighth Circuit later adopted Hamilton Watch in a government suit. United States v. Aluminum Co. of America, 247 F. Supp. 308, 314 (E.D. Mo. 1964), affd, 382 U.S. 12 (1965). 
Sonesta International Hotels Corp. $v$. Wellington Associates. ${ }^{79}$ Sonesta involved another attempt to forestall a hostile takeover, this time on the ground of alleged violation of securities regulations. The Second Circuit harmonized traditional equity standards with the Hamilton Watch approach to arrive at a two-pronged test:

[A] preliminary injunction should issue only upon a clear showing of either (1) probable success on the inerits and possible irreparable injury, or (2) sufficiently serious questions going to the merits to make thein a fair ground for litigation and a balance of hardships tipping decidedly toward the party requesting the preliminary relief. ${ }^{80}$

After Sonesta, the language of Hamilton Watch clearly controls in the Second Circuit; the objection that the liberal wording-Frank's 'casual restatement-distorts the traditional rule is no longer of much force. Indeed, Sonesta is now cited as a matter of course $\mathrm{m}$ private antitrust litigation. ${ }^{81}$ Though use of the Hamilton-Sonesta approach in government antimerger cases was delayed ${ }^{82}$ in the Second Circuit until recently, the disposition of FTC $v$. Lancaster Colony Corp. ${ }^{83}$ substantially reduced any doubt concerning its applicability. The court for the Southern District of New York summarily held that the FTC had met its burden of proof in that case merely through a showing of serious and substantial questions.

Adoption of the Hamilton-Sonesta approach in governunent suits, however, has not been free of problems. United States v. Culbro Corp. ${ }^{84}$ an antimerger case decided shortly after Lancaster, illustrates the confusion that may arise in an attempt to retreat from the Sonesta standards. Judge Ward revived the irreparable harm requirement, holding that if the governinent was unable to demonstrate a reasonable probability of success, the court could not presume irreparable harm from the statutory ban on anticompetitive mergers. ${ }^{85}$ This approach

79. 483 F.2d 247 (2d Cir. 1973).

80. Id. at 250 (emphasis in original).

81. E.g., Jack Kahn Music Co. v. Baldwin Piano \& Organ Co., No. 79-7093 (2d Cir. Aug. 1, 1979); Jacobson \& Co. v. Armstrong Cork Co., 548 F.2d 438 (2d Cir. 1977); Triebwasser \& Katz v. A.T.\&T. Co., 535 F.2d 1356 (2d Cir. 1976); Missouri Portland Cement Co. v. Cargill, Inc., 498 F.2d 851 (2d Cir.), ccrt. denicd, 419 U.S. 883 (1974); In FTC v. PepsiCo, Inc., 477 F.2d 24 (2d Cir. 1973), the court never inentioned contemporary developments in the Hamilton Watch line and instead followed a more traditional line of government antitrust cases holding the FTC to a standard of a reasonable probability of success. PepsiCo read the Supreme Court's Dean Foods decision very narrowly and placed a heavy burden on the government. See notes $33 \& 34$ supra and text accoinpanying notes 31-34 supra.

82. See FTC v. PepsiCo, Inc., 477 F.2d 24 (2d Cir. 1973), where the court used the reasonable probability standard without ever mentioning contemporary developinents in the Hamilton Watch test.

83. 434 F. Supp. 1088 (S.D.N.Y. 1977).

84. 436 F. Supp. 746 (S.D.N.Y. 1977).

85. Id. at 750 . 
may represent a circuitous return to the reasonable probability standard; the government must show a likelihood of success whenever public injury is not amenable to direct proof-and it rarely is. Judge Ward went on to hold that even after a showing by plaintiff of a probability of success, the court must still weigh the equities, requiring im addition that the Justice Department show reasonable probability of harm to the public prior to full trial. ${ }^{86}$ Again, the court refused to presume harm from the statute. Ward's opinion clearly represents a cautious approach to the preliminary mjunction, an attempt to retreat from the liberal Sonesta rule.

The doubt and confusion caused by the Sonesta line is even more apparent in the Third Circuit. A strong line of cases following United States $v$. Ingersoll-Rand $\mathrm{Co}^{87}$ has established that the reasonable probability test prevails in that circuit, ${ }^{88}$ but district court cases have subjected this standard to substantial erosion. In fact, the history of the controlling Ingersoll-Rand decision illustrates the conflict between appellate and district court opinion. The court of appeals, in affirming the district court's holding, clearly used the reasonable probability standard without mentioning that the lower court in that case had applied the substantial questions test. ${ }^{89}$ A district court case decided two years later preferred the substantial questions standard and sustamed the Justice Department's attack on a merger. ${ }^{90}$

A recent private case from the Third Circuit frankly admits that the court turned to the substantial questions test because it provides a method of postponing difficult substantive decisions until full hearing. In Copperweld Corp. v. Imetal, ${ }^{91}$ the court acknowledged that the reasonable probability test prevails in the Third Circuit, but reasoned that "should the Circuit have occasion to rule on the matter in the context of a case such as the one before us, it would embrace the less strimgent criterion."92 Judge Miller's colorful opinion relied on Delaware River

86. Id.

87. 320 F.2d 509 (3d Cir. 1963). It is interesting to note that although this case is still controlling in the Third Circuit, Mr. Justice Goldberg's in chambers opinion in United States v. FMC Corp., 84 S. Ct. 4 (1963), raises serious doubts about the jurisdictional grounds on which it rests.

88. E.g., Allis-Chaliners Mfg. Co. v. White Consol. Indus. Inc., 414 F.2d 506 (3d Cir. 1969), cert. denied, 396 U.S. 1009 (1970); United States v. Chrysler Corp., 232 F. Supp. 651 (D.C.N.J. 1964).

89. Compare 320 F.2d at 525 (requiring "the probability of a lessening of competition and . . . reasonable probabihity of success on final hearing") with 218 F. Supp. 530, 544 (W.D. Pa. 1963) ("The ultimate legal issues involved in this action raise such serious and substantial questions . . . as to require that consummation be, at least, postponed until final hearing").

90. United States v. Pennzoil Co., 252 F. Supp. 962, 986 (W.D. Pa. 1965).

91. 403 F. Supp. 579 (W.D. Pa. 1975).

92. Id. at 587; see Vanadium Corp. v. Susquehanna Corp., 203 F. Supp. 686, 697 (1962). 
Port Authority v. Transamerican Trailer Transport, Inc., ${ }^{93}$ in which the Third Circuit held that a district court may, in its discretion, grant an injunction "even though plaintiffs did not demonstrate as strong a likelihood of ultimate success as would generally be required."94 Miller concluded that the novelty and complexity of the suit made determination of likelihood of success impractical in a preliminary proceeding. ${ }^{95}$ Merger cases, however, are invariably complex and frequently novel as well, and the substantial questions test will always offer an attractive alternative to sorting out a reasonable probability of success. This approach is clearly unsatisfactory, however, where the effect of a preliminary injunction is abandonment of merger plans.

Clearly, the balancing test has certain weaknesses, but the alternative sequential approach, requiring a reasonable probability of success, is equally vulnerable. The Clayton Act is an "incipiency" statute, designed to outlaw mergers that are reasonably likely to have anticompetitive effects. ${ }^{96}$ Thus, the test for a preliminary injunction should require a showing of a reasonable probability that the merger is reasonably likely to harm coinpetition. Rather than attempting such an awkward approach, however, the courts have sometimes chosen to abridge the test, demanding merely a showing of a reasonable likehhood of anticompetitive impact. ${ }^{97}$ This showing is substantially identical to that required at ultimate hearing and may be too stiff a requirement for preliminary relief. ${ }^{98}$ The parties are simply unprepared to present a full-blown antitrust analysis in a preliminary proceeding, and the courts are understandably hesitant to arrive at a decision on the likelihood of success with only a tentative analysis of fact and law. ${ }^{99}$ Thus, although the substantial questions test presents

93. 501 F.2d 917 (3d Cir. 1974).

94. Id. at 923. In fact, the Delaware River decision may come to supersede the IngersollRand case as the controlling precedent. See Constructors Ass'n of W. Pa. v. Kreps, 573 F.2d 811 (3d Cir. 1978); Obury v. Shapp, 521 F.2d 142 (3d Cir. 1975).

95. 403 F. Supp. at 587.

96. See, e.g., Brown Shoe Co. v. Umited States, 370 U.S. 294, 317-18 (1962).

97. E.g., United States v. Ingersoll-Rand Co., 320 F.2d 509, 525 (3d Cir. 1963) (requiring a showing of a probable lessening of competition).

98. See House REPORT 7-8 ("Focused as it is on probabilities, this standard for injunctive relief is little different from the steep one forced by [sic] the government at a trial on the inerits . . ."); Senate Hearings, pt. I, at 503 (statement of Professor Joseph F. Brodley) ("the Government lias been put to the same standard of proof on the motion for preliminary injunction which it must face at the ultimate trial"); $i d$., pt. II, at 1002 (letter from Thomas Kauper, Assistant Attorney General, Antitrust Division, to Senator Hart) ("In practice, it has frequently been necessary to convince the trial court of the ultimate inerits of the case').

99. Id., pt. I, 505 (statement of Professor Joseph F. Brodley) ("[The government] is unprepared on an early record to make that kind of showing. . . . The case is simply not ripe"). See FTC v. Atlantic Richfield Co., 549 F.2d 289, 294 (4th Cir. 1977) ("it is difficult, if not impossible, 
problems im equity jurisprudence and practice, the alternative, the reasonable probability test, provides no easy answers.

The district courts are therefore caught in a dilemma when choosing between the sequential and balancing approaches: the reasonable probability test is too complex and awkward to be practical at a prelimmary hearing; the substantial questions test is too cursory and superficial to be appropriate where the decision may have the effect of final relief. It is hardly surprising that courts faced with this dilemma have adopted an intuitive approach to the problem, choosing between the tests as necessary to preserve the status quo or the possibility of an adequate remedy after final decision. ${ }^{100}$ What may be surprising is that the pattern currently einerging is one of broad acceptance of the balancimg approach in private antimerger litigation and adherence to the reasonable probability test in government suits.

The various weaknesses in the balancing approach are primarily the result of this government plaintiff-private plaintiff dichotomy. The Sonesta line developed exclusively in the context of private actions, and it was the application of this approach to government suits that led to rejection of the test in Brown Shoe ${ }^{101}$ and confusion of the test in Culbro. ${ }^{102}$ While the Fourth, ${ }^{103}$ Sixth, ${ }^{104}$ and Ninth ${ }^{105}$ Circuits have

to determine the FTC's chances of ultimate success when the law is so uncertain and the parameters of the [potential entrant] doctrine obscure"); FTC v. Lancaster Colony Corp., 434 F. Supp. 1088 (S.D.N.Y. 1977) (no extensive analysis of antitrust issues necessary in preliminary proceeding under Clayton § 7); Copperweld Corp. v. Imetal, 403 F. Supp. 579, 587 n.13 (W.D. Pa. 1975) (case "rife with factual and legal complexities" that are not "readily annenable to preliminary adjudication"); Dalmo Sales Co. v. Tysons Corner Regional Shopping Center, 308 F. Supp. 988 (D.D.C.), affd, 429 F.2d 206 (D.C. Cir. 1970) (novel legal issues imvolved in antitrust action precluded issuance of preliminary imjunction).

100. See text accompanying note 7 supra.

101. 1956 Trade Cas. If 68,244 (E.D. Mo. 1956). See text accompanymg notes 75-78 supra.

102. 436 F. Supp. 746 (S.D.N.Y. 1977). See text accompanying notes $84-86$ supra and notes 163-65 infra.

103. See text accompanymg notes 106-08 infra.

104. Compare Brandeis Mach. \& Supply Corp. v. Barber-Greene Co., 503 F.2d 503, 505 (6th Cir. 1974) (employing the Hamilton Watch standard) and Beaute Craft Supply Co. v. Revlon Inc., 402 F. Supp. 385, 388-89 (E.D. Mich. 1975) (relaxing standard on merits in antitrust case) with United States v. White Consol. Indus., Inc., 323 F. Supp. 1397, 1400 (N.D. Ohio 1971) (using probability of success requirement).

105. Compare William Inglis \& Sons Baking Co. v. I.T.T. Contimental Baking Co., 526 F.2d 86, 88 (9th Cir. 1975) (adopting "alternative test" of the Second Circuit) with United States v. Coca-Cola Bottling Co., 575 F.2d 222, 226 (9th Cir. 1978) (citing with approval lower court's use of substantial likelihood test) and United States v. FMC Corp., 218 F. Supp. 817, 823 (N.D. Cal.), appeal dismissed, 321 F.2d 534 (9th Cir.), application for preliminary injunction denied, 84 S. Ct. 4 (1963) (per Goldberg, J. in chambers) ("clear probability" of success necessary). But see United States v. Tracinda Inv. Corp., 5 TRADE REG. REP. | 62,445 (C.D. Cal. 1979) (allowing for possibility of using Sonesta in government suit where government shows "decided tipping of the equities"). 
followed Hamilton, the substantial questions test has yet to be applied in a government suit in any of those jurisdictions. The Fourth Circuit's decisions are particularly apposite here, in view of the fact that a 1977 appellate decision liberalizing the standard for a private plaintiff ${ }^{106}$ caine only one inonth after another appellate decision requiring a strict standard of proof and a showing of probability of success from the FTC. ${ }^{107}$ In addition, a Fourth Circuit ruling only six months earlier held that the FTC met its burden of a "substantial likelihood of success." 108 Although no court lias specifically addressed this distinction between government and private suits or attempted to explain it, it clearly exists.

Commentary attempting to justify the distimction between government and private cases is not entirely convincing. ${ }^{109}$ The theory is that the government, in contrast to the private plaimtiff, is unlikely to abandon its suit after failing to obtain a preliminary injunction. The government's resources are not as limited as those of a private plaintiff, and while the government has the alternative of divestiture, that remedy may be unavailable to the private plaintiff. The denial of a preliminary injunction is more likely to have the effect of final relief in a private action, thus making the inore liberal substantial questions test appropriate. ${ }^{110}$ This arguinent seeins rather weak, however, because the government's resources are actually quite limited. ${ }^{111}$ Furtliermore, if divestiture is an inadequate remedy, its availability in government suits should make little difference in terms of the applicable test.

There is a inore compelling reason for rejection of Sonesta in government suits. Many of the difficulties with the balancing approach may be traced to the origin and developinent of the Sonesta line of cases; that standard evolved solely in private antitrust actions where the irreparable injury and balance of liardship requireinents are of great importance, and it is far less appropriate in government suits where presumptions of injury often control. The substantial questions test is now triggered by a "decided imbalance" of the equities, but the Sonesta approach gives courts little guidance as to the relative weights

106. Blackwelder Furniture Co. v. Seilig Mfg. Co., 550 F.2d 189 (4th Cir. 1977).

107. FTC v. Atlantic Richfield Co., 549 F.2d 289 (4th Cir. 1977).

108. FTC v. Food Town Stores, 539 F.2d 1339, 1344 (4th Cir. 1976), vacated as moot, 547 F.2d 247 (4th Cir. 1977).

109. N.Y.U.L. Rev. Note at 776-77.

110. Id. 776-77.

111. See Senate Hearings, pt. I, at 137 (statement of Ralph Nader and Mark Greene, Corporate Accountability Research Group) ("for too long antitrust enforcement has been an ant eyeing an elephant-an under-funded and handicapped Federal program unable to contend with the great corporate power of our dominant firms"). 
of the required showings even in private suits. The point at which the equities "tip decidedly" is necessarily less clear in government suits where a somewhat nebulous public injury inust be balanced against concrete and measurable private hardship. ${ }^{112}$ Because dainage to the public interest is not ainenable to direct proof, courts often presuine such injury froin the existence of a statute, particularly a statute which specifically authorizes a preliminary injunction. ${ }^{113}$ The utility of Sonesta is extreinely doubtful in government cases: it is all but impossible to determine when the balance tips decidedly in favor of a public injury which is inerely presumed as opposed to a private harm which is clearly identifiable.

Thus, inodern trends to reduce the required showing on the inerits are coming into conflict with developments on the requisite showing on the equities. In order to understand this conflict more fully, it is necessary to examine the recent developinents on the equities, particularly the Fourth Circuit's refusal to consider any private injury in weighing the equities.

\section{B. The Balance of the Equities: The Fourth Circuit Excludes Consideration of the Respondent's Injury.}

The Fourth Circuit has imitiated what is obviously the inost hiberal developinent in the required showing on the equities. The holding in FTC v. Food Town Stores, Inc. ${ }^{114}$ inarks a radical departure from the orthodox rules of equity; the court held that in section 13(b) proceedings private injuries that respondents might suffer as a result of the injunction did not even merit consideration. ${ }^{115}$ Judge Winter, sitting as the single judge, refused to weigh a number of contingencies, among thein the possibility of a lawsuit by a creditor or by stockholders, the necessity of anending the SEC registration stateinent, a possible decline in the value of Foodtown's stock and the ultimate abandonment of the inerger. ${ }^{116}$ Winter ruled that these and other serious hardships

112. See Carrier Corp. v. United Technologies Corp., 5 Trade REg. REP. (CCH) I 62,393, at 76,378 (N.D.N.Y. 1978), aff'd, 5 TRADE REG. REP. (CCH) I 62,405 (2d Cir. 1978) ("The injury which . . . the Government might suffer if a preliminary injunction is denied is remote and speculative in nature. On the other hand, the injury which United and the Carrier shareholders would suffer if a preliminary injunction were granted is real and immediate"); Senate Hearings, pt. I, at 294 (statement of Milton Handler) ("I am asking you, in turn, to give ine a concrete case where an antitrust violation has affected the general econoiny of the State in such a way as to be capable of monetary ineasurement. . . . [W]ith all respect to the learned Senator from the State of Michigan, I defy you to give me such a state of facts"). See cases cited note 147 infra.

113. See text accompanying note 15 supra.

114. 539 F.2d 1339 (4th Cir. 1976), vacated as moot, 547 F.2d 247 (4th Cir. 1977).

115. Id. at 1346.

116. Id. at 1345 . 
go to

the private injury which may result from an injunction delaying the merger. I do not minimize them, but I conclude that they are . . . not proper considerations for granting or withholdimg injunctive relief under $\S 13(\mathrm{~b})$. My conclusion in this respect is reinforced by recogmition that inany of them would result if any merger is enjoined on the eve of its consummation; yet Congress enacted \& 13(b) authorizing injunctive relief, thereby indicating that it thought that little weight should be given to them. ${ }^{17}$

Winter did consider possible public benefits fiowing from the acquisition, but characterized them as too speculative to outweigh the public injury involved in an anticompetitive merger. ${ }^{118}$ In sum, Food Town apparently established an almost irrebutable presumption in favor of the government on the equities.

The language of section 13(b) is open to Winter's interpretation. The statute gives the district courts power to issue a preliminary injunction where, "weighing the equities and considering the Commission's likelihood of success, such action would be in the public interest."119 Judge Winter read the statute as if the requireinent of balancing the equities was centered on the public interest standard. Thus, the einphasis of section 13(b)'s language-anbiguous as it may be-led Winter to infer that Congress was referring only to "public equities." Under this interpretation, a corporation inay introduce evidence of public benefit deriving from a merger ${ }^{120}$ but cannot rely on the injnnction's direct impact on the firms involved.

The statute's language seeins inadequate to justify Winter's sharp break with longstanding principles of equity, and the Food Town rule is therefore subject to serious criticisin. The holding, however, is based largely on the legislative history of section 13(b). Wimter cited the House Committee Report to deinonstrate the mtent "to inaintain the statutory or 'public interest' standard which is now applicable and not to impose the traditional 'equity' standard."121 The report went on to comment that the traditional tests are not "appropriate for the implementation of a Federal statute where the standards of the public inter-

117. Id. at 1346 (emphasis in original).

118. Id. (lower retail food prices are in public interest but are suspect as possibly predatory).

119. 15 U.S.C. $\$ 53$ (b) (1976). See note 36 supra for complete text.

120. Because public benefits-like public mjury-are not amenable to direct proof, and because presuinptions run in favor of the government, it is difficult to see how the defendant could ever prevail under the Food Town approach.

121. 539 F.2d at 1343 (quoting H.R. REP. No. 624, 93d Cong., 1st Sess. 31 (1973), reprinted in [1973] U.S. Code CoNG. \& AD. News 2523, 2533) (both authorities incorrectly citing H.R. REP. No. 624 as 924). 
est measure the propriety and need for injunctive relief." 122 Winter poimted out that this language was intended to codify decisional law in cases $^{123}$ interpreting section 13(a) of the Federal Trade Commission Act, ${ }^{124}$ an injunction statute substantially similar to section $13(b)$ but applicable only to advertising. While there is some indication in the case law that weighing of private harm is unnecessary under section 13(a), ${ }^{125}$ the better-reasoned majority view is that of FTC v. National Health Aids, Inc.: ${ }^{126}$ "The reasonable belief of the Commission is sufficient to warrant its application for the injunction, but the action of the Court should be based on the general considerations that properly apply im the issuance of preliminary injunctions." ${ }^{127}$ Thus, Winter's view of the statute is not without support, but that support is undercut by majority opinion and well-reasoned commentary. ${ }^{128}$ The statute clearly is designed merely to eliminate the requirement of irreparable harm, and not to foreclose consideration of private imjury.

Further development of the Food Town rule may be strictly hinited. Only one district court, the Lancaster court in the Second Circuit, has explicitly followed Winter's refusal to consider private hardship. ${ }^{129}$ The Fourth Circuit itself may have signalled a retreat: in FTC v. Atlantic Richfield Co. ${ }^{130}$ the panel reworded the standards to allow weighing of public and private injury. ${ }^{131}$ Atlantic Richfield is distmguishable from Food Town on jurisdictional grounds, ${ }^{132}$ but the case does evidence a reluctance to follow the unorthodox Food Town holding.

122. Id.

123. See FTC v. Sterling Drug, Inc., 317 F.2d 669 (2d Cir. 1963); FTC v. National Health Aids, Inc., 108 F. Supp. 340 (D. Md. 1952).

124. 15 U.S.C. $\$ 53$ (a) (1970).

125. E.g., FTC v. Rhodes Pharmacal Co., 191 F.2d 744 (7th Cir. 1951) (rational basis for FTC's challenge held sufficient to justify preliminary injunction).

126. 108 F. Supp. 340 (D. Md. 1952).

127. Id. at 346. Furthermore, $\S 13(\mathrm{~b})$ includes the language "weighing the equities and considering the Commission's likclihood of ultinate success," 15 U.S.C. $§ 53(\mathrm{~b})$ (1976), which directs the court toward the traditional equitable standards. Section 13(a) omits this language. Thus, there is more reason to use traditional standards under $\S 13(\mathrm{~b})$ than under $\S 13(\mathrm{a})$. See FTC v. National Comm'n on Egg Nutrition, 517 F.2d 485 (7th Cir. 1975), cert. denied, 426 U.S. 919 (1976). But see FTC v. Rhinechein Corp., 5 TRADE REG. REP. (CCH) I 62,350, at 76,112-13 (N.D. Ill. 1978) ("To achieve its goal of facilitating successful governmental intervention before [consuinmation of a inerger], Congress has rendered the traditional equity requirements inapplicable in a section 13(b) suit").

128. E.g., 65 HARv. L. REv. 349 (1951). See Annot., supra note 37.

129. FTC v. Lancaster Colony Corp., 434 F. Supp. 1088 (S.D.N.Y. 1977); see FTC v. Rhinechem Corp., 5 TRADE REG. REP. (CCH) \ 62,350 (N.D. Ill. 1978).

130. 549 F.2d 289 (4th Cir. 1977).

131. Id, at 292 .

132. Atlantic Richfield was decided under 15 U.S.C. \$25 (1976); Food Town was decided under 15 U.S.C. $\$ 53($ b) (1976). The language of the two statutes is substantially different. See notes 34 \& 36 supra. 
Many courts, however, have adopted a line of reasoning similar to that in Food Town. Some courts, while avoiding an absolute refusal to consider private harm, have held that the public interest in effective antitrust enforcement is entitled to great weight and that private hardship must be extreme before the balance can be tipped in respondent's favor. In United States v. Atlantic Richfield Co. ${ }^{133}$ the district court held that the defendants' possible injuries were "entitled to serious consideration" but concluded that "they cannot outweigh the public interest in preventing this merger froin taking effect pending trial. . . . The public interest with which Congress was concerned in enacting Section 7 is paramount." 134 A Third Circuit district court has held that "the public interest in preserving a free-competitive [sic] econolny cannot be outweighed by any private interest." 135 Courts seein almost hostile at times to corporate interests: "The public interest in preventing a violation of Sec. 7 outweighs considerations of losses to speculating or $\mathrm{m}$ vesting stockholders . . .."136 In general, these courts have given little weight to corporate injury; the public interest will prevail except im extraordinary circumstances.

Other courts have taken a less doginatic approach and have attempted to reach a compromise between the important public interest in preventing antitrust violations and the serious private harm often caused by a preliminary imjunction. The district court in United States v. Pennzoil Co. ${ }^{137}$ attempted to find a compromise on the equities standard: "[The showing of defendants' injury] must be so proportionately persuasive as to submerge the primciple that ' $[t]$ he status of public interest and not the requirements of private litigation measure the propriety and need for relief." "138 More frequently, the courts have used a coinpromise remedy, allowing the inerger to go through but issuing a holdseparate order to keep the assets and securities of the acquired firm intact. ${ }^{139}$ The Second Circuit in FTC v. PepsiCo, Inc., ${ }^{140}$ issuing a hold-separate order, went so far as to allow consideration of the intent

133. 297 F. Supp. 1061 (S.D.N.Y. 1969), affd sub nom. Bartlett v. United States, 401 U.S. 986 (1971)

134. $297 \mathrm{~F}$. Supp. at 1073-74; see id. at $1074 \mathrm{n} .21$ ("The failure of Congress to require that the Government show irreparable loss . . . in a Section 7 action . . . indicates the Congressional desire to lighten the burden generally imposed on an applicant for preliminary injunctive relief").

135. United States v. Ingersoll-Rand Co., 218 F. Supp. 530, 543 (W.D. Pa.), affd, 320 F.2d 509 (3d Cir. 1963).

136. United States v. Chrysler Corp., 232 F. Supp. 651, 657 (D.N.J. 1964).

137. 252 F. Supp. 962 (W.D. Pa. 1965).

138. Id. at 986 .

139. See note 159 infra and text accompanying notes 156-59 infra.

140. 477 F.2d 24 (2d Cir. 1973). 
of the acquiring firm in determining the balance of hardships. ${ }^{141}$ Courts in the Second and Eighth Circuits have also used the compromise remedy to avoid inequity. ${ }^{142}$ The prevailing atmosphere in these courts is a sort of "strict scrutiny" in antitrust cases, with a heightened sensitivity to the strong public interest.

Many of the courts' problems on the equities arise in attemptimg to assess the extent of the public injury imvolved in any given case. It is all but impossible to place a definite value on intangible injury to local or national competition. ${ }^{143}$ There are two approaches to this problem: a court may emphasize the public interest in preventing violations of antitrust laws, relymg generally on the antitrust statutes as expressions of public policy; ${ }^{144}$ alternatively, a court may stress foreseeable and particular components of injury to consumers, competitors or, im the case of liostile tender offers, the acquired entities. ${ }^{145}$ The results of these two approaches are often disparate: emphasis on the public's interest in statutory enforcement usually precludes a balance in favor of the merger, ${ }^{146}$ while more detailed analysis of public and private mjury gives defendants an opportunity to show tangible harm and the government evidentiary problems. ${ }^{147}$ Food Town and similar cases illustrate that the first approach is increasingly becoming the rule; there is a very strong presumption that the equities weigh in the government's favor.

The presumptions are buttressed by the courts' abandonment of another traditional rule, that a preliminary imjunction will not issue where the result is to give petitioner the effect of final relief. ${ }^{148}$ Normally, equity seeks to mamtain the status quo with a preliminary injunction. In the context of mergers and acquisitions, however, preserving the status quo is often impossible, as the deal, if enjoined, cannot be held together pending final judgment, and the inerger, if allowed, will irrevocably alter the competitive situation. ${ }^{149}$ One coln-

141. Id. at 27.

142. United States v. Culbro Corp., 436 F. Supp. 746 (S.D.N.Y. 1977); United States v. Brown Shoe Co., 1956 Trade Cas. If 68,244 (E.D. Mo. 1956).

143. See note 112 supra.

144. E.g., FTC v. Food Town Stores, Inc., 539 F.2d 1339 (4th Cir. 1976), vacated as moot, 547 F.2d 247 (4th Cir. 1977).

145. E.g., FTC v. PepsiCo, Inc., 477 F.2d 24 (2d Cir. 1973).

146. E.g., FTC v. Lancaster Colony Corp., 434 F. Supp. 1088 (S.D.N.Y. 1977).

147. E.g., United States v. Tracinda Inv. Corp., 5 TrADE REg. REp. (CCH) \ 62,445, at 76,627 (C.D. Cal. 1979) ("plaintiff (and the public) will sustain no injury at all if [injunctive rehef] is denied"); United States v. Culbro Corp., 436 F. Supp. 746 (S.D.N.Y. 1977).

148. E.g., Triebwasser \& Katz v. A.T.\&T. Co., 535 F.2d 1356, 1360 (2d Cir. 1976); United States v. Northwest Indus., Inc., 301 F. Supp. 1066 (N.D. III. 1969). See Schneiderman, supra note 7, at 589-97; Developments in Law, supra note 15, at 1058; N.Y.U.L. REv. Note 779.

149. Senate Hearings, pt. I, at 529 (statement of Robert A. Longman, Chairman, Antitrust Section, New York State Bar Association); id. 513 (statement of Professor Joseph F. Brodley) 
mentator has argued that the courts appear to be sensitive to this problem and are unwilling to issue an mjunction where its effect would be to kill the merger. ${ }^{150}$ One has only to look to cases such as Food Town and Lancaster, however, to realize that courts no longer find persuasive respondents' fears that the mjunction will have the effect of final relief.

In rejecting this traditional rule of equity, the courts are often imfluenced by the madequacy of divestiture after litigation as a remedy. In the early 1960 s, divestiture may have been considered the usual remedy im merger cases; but as the courts became aware of Congress' contimumg dissatisfaction with the results of divestiture, they turned to the preliminary injunction as a more effective tool for antitrust enforcement. ${ }^{151}$ The preliminary imjunction seemed the most appropriate remedy to prevent anticompetitive effects in their incipiency, before the monopolistic effect grew to Sherman Act proportions. ${ }^{152}$ Increasing congressional discontent with divestiture ${ }^{153}$-as indicated by the amendment of the Federal Trade Commission Act to facilitate imjunctive relief ${ }^{154}$-led the courts to reject respondents' claims that the imjunction had the effect of final judgment. ${ }^{155}$ Defendants' ability to tip the balance of the equities was correspondingly reduced.

The availability of alternatives to divestiture is likely to be of some assistance to corporate defendants on the equities. Theoretically, the compromise hold-separate order keeps open the possibility of divestiture even after years of litigation. ${ }^{156}$ Authoritative commentary, however, has criticized the hold-separate order on the ground that it is scarcely more effective than divestiture alone. ${ }^{157}$ A recent landmark

("two writers with practical experience, one an enforcement official of the Department of Justice, have suggested that merging partners have usually abandoned their proposed merger when the government has obtained a preliminary injunction"); id., pt. II, at 1034 (memorandum from the Securities Industry Association); N.Y.U.L. Rev. Note 771-72. See notes 11 \& 12 supra.

150. N.Y.U.L. REv. Note 775.

151. See FTC v. Food Town Stores, Inc., 539 F.2d 1339, 1343 (4th Cir. 1976), vacated as moot, 547 F.2d 247 (4th Cir. 1977); FTC v. Rhinechem Corp., 5 TRADE REG. REP. (CCH) I 62,350 (N.D. Ill. 1978); FTC v. Lancaster Colony Corp., 434 F. Supp. 1088 (S.D.N.Y. 1977); Unitcd States v. Atlantic Richfield Co., 297 F. Supp. 1061, 1073 (S.D.N.Y. 1969), affd sub nom. Bartlett v. United States, 401 U.S. 986 (1971) (interpreting the legislative history of Clayton Act $\S 15$ to require liberal standards).

152. E.g., Brown Shoe Co. v. United States, 370 U.S. 294, 317-18 (1962).

153. See notes $4,42-43$ supra.

154. See notes 36-37 supra.

155. See cases cited in note 151 supra.

156. See FTC v. PepsiCo, Inc., 477 F.2d 24 (2d Cir. 1973); Uurited States v. Culbro Corp., 436 F. Supp. 746 (S.D.N.Y. 1977); United States v. Brown Shoe Co., 1956 Trade Cas. I 68,244 (E.D. Mo. 1956). But see United States v. Wilson Sporting Goods Co., 288 F. Supp. 543, 567 (N.D. Ill. 1968).

157. Sullivan $\$ 215$, at 670 ; Note, supra note 18 , at 165 . 
case has held that rescission may be used to remedy an anticompetitive merger. ${ }^{158}$ The availability of rescission, which would eliminate some of the problems of divestiture, ${ }^{159}$ might encourage the use of hold-separate orders with an eye toward rescission rather than divestiture. A more attractive approach would be the consolidation of hearings on the preliminary mjunction with full trial, as authorized by the Federal Rules of Civil Procedure. ${ }^{160}$ In cases where trial can be expedited, ${ }^{161}$ this approach avoids not only the hardships worked by prolonged preliminary rehef but also the problems of divestiture. The consolidation of hearings, as well as the use of rescission, will not be practical or appropriate in every case, but the availability of relief less drastic than the preliminary injunction provides some counterweight to modern presumptions that the equities are in the government's favor.

Despite recent use of alternatives to divestiture, presumptions in the government's favor are still quite strong, and these presumptions, coupled witl limitations on defendants' showing on the equities, make Sonesta's balancing test extremely difficult to apply im government suits. Because the government's case usually relies heavily on the strength of the public interest in effective enforcement, ${ }^{162}$ it is all but impossible to determine when the substantial questions standard should be triggered. An even more forceful argument agamst the use of Sonesta im government suits is that public mjury can be presumed only when the government has shown a reasonable probability of success on the merits. The presumption of harin is derived from the threatened violation of the Clayton Act, but if the government fails to show a likelihood of success, there is no real reason to suspect that the law will be broken or to presume injury to competition. Thus, the balancing approach is at odds with modern treatment of the equities: when the government relies on the serious and substantial questions test, the courts sliould also require a showing of a serious threat of public injury-a requirement which Congress and the courts have eliminated.

The federal courts have not dealt with this issue explicitly, but at least one holding, the Culbro decision by Judge Ward, appears to have

158. United States v. Coca-Cola Bottling Co., 575 F.2d 222 (9th Cir. 1978).

159. Rescission would eliminate the problem of finding a buyer whose acquisition would not have any anticoinpetitive effect. See Elzinga, supra note 42, at 61-66.

160. FED. R. CIv. P. 65(a)(2).

161. E.g., United States v. Consol. Foods Corp., 1978-1 Trade Cas. I 62,110 (E.D. Pa. 1978) (not fundamentally unfair to force government to have its case ready within 133 days of filing complaint where government waited four and a half unonths after announceinent of inerger to file complaint and had familiarity with industry from previous litigation).

162. See cases cited in note 15 supra. 
intuitively sensed the problem. ${ }^{163}$ In applying the substantial questions test, Ward eliminated the presumption of irreparable harm and required a showing of probability of actual public injury. ${ }^{164}$ Thus, the Culbro case attempted to square the Sonesta test with modern treatment of the equities in government cases. The attempt may not have been conceptually satisfying, especially when Congress had eliminated the irreparable harm requirement, ${ }^{165}$ yet such a move was necessary to reconcile incompatible developments in the law.

\section{Summary: Standards for a Preliminary Injunction.}

The law of the preliminary imjunction remains in a state of flux, with the greatest uncertainty in the showings required in a government action. If the spread of the Sonesta approach throughout the circuits is an accurate indicator, that test may become standard even in governinent suits. Furthermore, the next step in the development of the Sonesta line must be the elimination of the decided imbalance of the equities as the trigger for the substantial questions test. This change may be effected in two ways: first, by giving the government an irrebutable presumption that the balance tips decidedly in its favor and so allows the lesser burden of Sonesta; ${ }^{166}$ and second, by resorting to Sonesta's substantial questions test merely to postpone consideration of coinplex substantive issues regardless of the equities. ${ }^{167}$ Contemporary developments in the treatment of the equities may limit further hiberalization of the requirements on the inerits; the courts may be beginning to realize that presumptions of harm make Sonesta inappropriate in government suits. ${ }^{168}$ The availability of rescission and consolidation of

163. United States v. Culbro Corp., 436 F. Supp. 746 (S.D.N.Y. 1977).

164. Id. at 750 .

165. 15 U.S.C. $\S 25$ (1976); see United States v. Atlantic Richfield Co., 297 F. Supp. 1061, 1074 n.21 (S.D.N.Y. 1969), affd sub nom. Bartlett v. United States, 401 U.S. 986 (1971).

166. See FTC v. Lancaster Colony Corp., 434 F. Supp. 1088 (S.D.N.Y. 1977). In FTC v. Rhinechenı Corp., 5 TRADE REG. REP. (CCH) I 62,350, at 76,108 (N.D. Ill. 1978), the court followed the Lancaster approach and took the view that the serious and substantial questions test is to be applied in section 13(b) proceedings regardless of the equities: "Although this record might not support injunctive relief under the traditional equiptable [sic] standard, which demands . . . a 'reasonable likelihood of success on the inerits' ... it is deemed sufficient to merit the rehef requested under section 13(b)." Id. at 76,111. The court went on to hold that a showing of serious and substantial questions is adequate to raise a strong presumption of harm in the government's favor. Id. at 76,113. The court based its departure from the traditional standards of equity on the legislative history of section 13(b). See text accompanying notes 114-28 supra.

167. See Copperweld Corp. v. Imetal, 403 F. Supp. 579 (W.D. Pa. 1975). Uuder the Sonesta standard, the complexity of the problems raised may be more important than the strength of the plaintiff's case. If the test is improperly applied, without regard to the equities, then the Sonesta approach may give the plaintiff the effect of final relief without any showing that Clayton $\S 7$ has been violated or any showing of interim harm.

168. See United States v. Culbro Corp., 436 F. Supp. 746 (S.D.N.Y. 1977). See text accompa- 
hearings will weigh against use of the drastic preliminary injunction. These last conclusions, however, nay be premature: the Lancaster decision did combine the substantial questions test with a refusal to consider any private harm. ${ }^{169}$ Under this approach, the traditional standards of equity are nothing more than traditions.

\section{IMPACt OF THE New Report-AND-Wait Rules: The GOVERNMENT's SHOWING ON THE LIKELIHOOD OF SUCCESS}

In light of the complexity of antitrust litigation, the FTC has issued a very comprehensive report form designed to obtain any and all inforınation that inay be useful in seeking preliminary relief. ${ }^{170}$ The FTC has required that the reporting firm disclose the extent of its looldings after the planned acquisition; the structure of its doinestic corporate family; its products, sales and revenues; and the securities it has issued or liolds. Further, the reporting form denands copies of all surveys, analyses or similar studies conducted in preparation for the acquisition. ${ }^{171}$ While this last requirement may be difficult to enforce, particularly if the studies emphasize antitrust aspects of the acquisition, ${ }^{172}$ it does serve as an accurate indicator of the depth of the FTC's investigation under the new rules. Finally, the reporting statute merely requires substantial compliance, ${ }^{173}$ but the FTC's reporting rules are satisfied only by total compliance, as the Commission has held the requirements to the minimum necessary for effective enforcement. ${ }^{174}$

nying notes 163-65 supra. The Culbro approach-with its requirement that the government show probability of actual harm to trigger the substantial questions test-may in fact be the only way to incorporate Sonesta into government suits. If the government shows only serious and substantial questions, it unust also show actual harm. In Carrier Corp. v. United Technologies Corp., 5 Trade Reg. ReP. (CCH) \ 62,393 (N.D.N.Y.), affd, 5 TRAdE REg. ReP. (CCH) \ 62,405 (2d Cir. 1978), the district court, in applying Sonesta, considered the government's showing of irreparable injury. The Second Circuit, however, questioned the standards used below, pointing out that the government nced not nuake the showing required of a private plaintiff. The best solution to the problem of presuinptions of public mjury niay be to abandon Sonesta entirely in government suits.

169. FTC v. Lancaster Colony Corp., 434 F. Supp. 1088 (S.D.N.Y. 1977).

170. 43 Fed. Reg. 33,443 (Aug. 4, 1978). See United States v. Ingersoll-Rand Co., 218 F. Supp. 530 (W.D. Pa.), affd, 320 F.2d 509 (3d Cir. 1963), for a listing of the types of information the government has usually sought but has had difficulty in obtaining.

171. 43 Fed. Reg. 33,447 (Aug. 4, 1978).

172. Item 4(c) of the report form requires copies of "all studies, surveys, analyses and reports . . . prepared 'by or for any officer(s) or director(s)' . . for the purpose of evaluating or analyzing the acquisition." Id. 33,525. The requirement that the studies be done by or for officers or directors opens a rather large loophole; a report nominally done by or for someone other than an officer or director inay cross the desks of all officers and directors.

173. 15 U.S.C. \& $18 \mathrm{a}(\mathrm{g})(2)$ (1976).

174. 43 Fed. Reg. 33,508-09 (July 31, 1978). 
The meaning of total compliance is uncertain; the FTC requests information which the reporting firm may or may not have, particularly as to the extent of overlap in sales or operations of acquiring and acquired firms. Supplemented by the FTC's powers to delay or extend the waiting period and to request additional information, ${ }^{175}$ however, the report form should be able to reach all relevant information.

The data required under the regulations is exactly that which courts have considered important in determining the government's likelihood of success on the merits. The language of the Clayton Act"where in any line of commerce in any section of the country, the effect of such acquisition inay be substantially to lessen competition, or to tend to create a inonopoly"176 - controls in the court's evaluation of the probability of success. Thus, courts look first to the relevant product lines, the relevant geographic inarket, and the firms' quantity of sales and inarket share of that product. ${ }^{177}$ All this information will be readily available to the enforcement agencies through the new reporting rules and market census data from government sources or froin private industrial associations. ${ }^{178}$ Courts then proceed to consider these findings in light of other evidence: first, whether the inerger is primarily vertical, horizontal or conglomerate in nature; second, the firms' coinbined share of inarket resources and sales; third, the degree of concentration of production in the industry; fourth, any trend toward concentration in the industry; fifth, difficulty of entry into the industry; sixth, elimination of a substantial competitor; and finally, possible development of reciprocal relationships due to increase in market power. ${ }^{179} \mathrm{~A}$ brief analysis of the new reporting form shows that it has been designed to deal with these issues.

The first item on the report form requires no inore than identification of the reporting firm and responses to a series of questions in a checklist format; items two and three, however, are far more extensive, requesting a detailed description of the acquisition. Basically, these

175. 15 U.S.C. $\S 18 \mathrm{a}(\mathrm{e})(1976)$.

176. 15 U.S.C. $\$ 18$ (1976).

177. E.g., United States v. Atlantic Richfield Co., 297 F. Supp. 1061 (S.D.N.Y. 1969), affd sub nom. Bartlett v. United States, 401 U.S. 986 (1971).

178. See U.S. Bureau of Census, 1972 Census of Manufacturers (1972); U.S. BureaU of Census, ANnual Survey of Manufacturers; U.S. Bureau of Census, CuRrent IndusTRIAL REPORTS.

179. E.g., FTC v. PepsiCo, Inc., 477 F.2d 24, 27 (2d Cir. 1973); United States v. IngersollRand Co., 320 F.2d 509, 524 (3d Cir. 1963) (also considering power to finance extended operations, completeness of product lines offered and ability to finance consumer purchases); United States v. Atlantic Richfield Co., 297 F. Supp. 1061, 1072 (S.D.N.Y. 1969), aff'd sub nom. Bartlett v. United States, 401 U.S. 986 (1971); United States v. Pennzoil Co., 252 F. Supp. 962,967 (W.D. Pa. 1965). 
items are designed to elicit information concerning the nature and extent of the control the acquiring firn will have after the acquisition. The antitrust agencies should have hittle difficulty with questions of control in the courts. Only acquisitions of more than fifteen percent of the assets or outstanding stock or acquisitions valued at more than $\$ 15$ million are subject to the reporting requirements. The courts will accept this level of ownership as adequate to bring the Clayton Act into play. ${ }^{180}$ The only problen here lies in distinguishing between acquisitions made to influence the management policies of the acquired firm and those made solely for investment purposes or in the norinal course of business. Because the latter types of acquisitions are specifically exempted from the reporting requirements, ${ }^{181}$ there may be some disagreement concerning the intent of the acquiring party. Such issues, however, rarely reach the litigation stage. ${ }^{182}$

Items four and six of the report form examine the fiscal perfornance, the corporate structure and the securities base of the acquiring firm. Item four requires the reporting firm to submit copies of SEC registration documents, ${ }^{183}$ annual reports, audits, surveys and studies prepared in planning the merger. This information, particularly the firm's internal memoranda, will aid the enforcement agencies in developing cases involving the potential entrant or toehold acquisition theories. ${ }^{184}$ This information may also be used to counter the failingcompany defense. ${ }^{185}$ Item six requires the reporting firm to disclose all

180. National Supply Co. v. Hillman, 57 F. Supp. 4, 7 (W.D. Pa. 1944); see House REPORT 23-24 (additional views of Rep. John Seiberhing) (recommending 10\% limit as adequate to show control).

181. 15 U.S.C. \& 18a(c)(9) (1976) (subject to a 10\% ceiling); 15 U.S.C. § 18a(c)(11) (1976) (applicable only to banks, banking associations, trust companies, investment companies and insurance companies).

182. But see FTC v. PepsiCo, Inc., 477 F.2d 24 (2d Cir. 1973).

183. All of the following, if fled with the SEC within three years prior to filing of notification, must be included in Item 4: the inost recent proxy statement, the most recent Form 10-K, all registration statements, all Forms 10-Q and 8-K and, if a tender offer, Schedule 14D-1. See 43 Fed. Reg. 34,447 (Aug. 4, 1978).

184. See FTC v. Atlantic Richfield Co., 549 F.2d 289 (4th Cir. 1977). Arco attempted to merge with a giant in the copper industry, the Anaconda Company. The two firms were not competitors. Under the potential entrant theory, however, the FTC could establish an antitrust violation by showing that "but for the merger, Arco could reasonably be expected . . . to becone an entrant into these markets and areas of coinpetition." $I d$. at 292. As Anaconda was a leader in copper markets, the FTC also argued that in order to preserve competition Arco should enter the industry with a toehold acquisition; that is, "market entry by acquisition of a sinaller firm already present in the market." Id. at 293 n.4. The court was not receptive to either theory at the preliminary stage of the hitigation, requiring "strict proof of any anticompetitive effect." Id. at 295.

185. In order to set up the "failing company" defense to a Clayton $\$ 7$ charge, the defendant must show that the resources of the acquired firm were "so depleted and the prospect of rehabilitiation so remote that it faced the grave probability of a business failure." International Shoe Co. v, FTC, 280 U.S. 291, 302 (1930). The defendant must also show that the acquiring company is 
entities within its corporate "family," all major shareholders, and all holdings from issuers outside the parent and its subsidiaries. These requirements will operate to bring out any possible anticompetitive effects that may result when different branches of a large firm, or various holdings in a large corporate or personal portfolio, begin to overlap in production.

Courts have been most concerned with the inforination provided in iteins five, seven, eight and nine. Under item five, the reporting firm inust disclose dollar revenues from each manufacturing industry in which it participates, froin each product that it manufactures, from each product class and from each non-manufacturing imdustry. This information will then be correlated with manufacturing census data to determine the firm's market share in relevant lines of commerce-the single inost important factor in antimerger litigation. ${ }^{186}$ Itein seven requests that the reporting firm list all states where it does business in any industry in whicli botli the acquiring and acquired persons participate. This data will assist the Commission and the Antitrust Division in establishing the relevant geographic markets for purposes of analyzing the lorizontal aspects of the proposed acquisition. The eighth item requires the reporting person to describe any vendor-vendee relationships ainong the inerging firms, thus providing the agencies with a data base to determine the extent of vertical integration involved in the proposed acqusition. Finally, iteen nine requires a list of prior acquisitions in industries where the present merger involves horizontal integration. This infornation will be useful in showing a trend toward concentration or an atteinpt to inonopolize. ${ }^{187}$

The inost serious problein with the current reporting system is the use of the standard industrial classification $\operatorname{codes}^{188}$ to define manufac-

the "only available purchaser." Citizen Pub. Co. v. United States, 394 U.S. 131, 138 (1969). See also United States v. General Dynamics Corp., 415 U.S. 486 (1974). In General Dynamics the depletion of the reserves of the acquired coal-mining firm was held inadequate to raise the "failing conipany" defense but was sufficient to defeat the government's showing of a substantial lessening of conpetition in long-term contracts. Id. at 508. The acquired firm, having committed substantially all of its reserves on prior contracts, was no longer an effective competitor for future contracts. Id.

For examples of the use of the failing company defense in government actions brought prior to a merger's consummation, see United States v. Amax, Inc., 402 F. Supp. 956 (D. Conn. 1975) ("failing company" defense inapposite where there were several alternative inerger partners; General Dynamics defense not available on facts) (merger voluntarily delayed pending final hearing) and United States v. Gimbel Bros., 202 F. Supp. 779 (E.D. Wis. 1962) (acquisition not likely substantially to lessen competition where business of acquired department store chain was declinnig and where firm had been forced to impair its working capital) (preliminary imjunction denied).

186. See cases cited in note 179 supra.

187. See, e.g., FTC v. PepsiCo, Inc., 477 F.2d 24, 27 (2d Cir. 1973).

188. Four-digit (SIC code) industry level: 1972 Standard Industrial Classification 
turing and non-manufacturing industries, products and product classes. The identification codes were not designed to set out lines of commerce for antitrust purposes, and their accuracy in determining whether industries or products are competitive is doubtful. There is also a problem of characterization under the codes, as it may be possible to mask anticompetitive effects by identifymg similar, competitive products with different code numbers. ${ }^{189}$ The problem is not imsoluble: enforcement agencies may eventually find it neeessary to have products identified with teclinical language that is standard in the trade.

The new reporting requirements will definitely aid the government in its showing of a likelihood of success. Firms planning an acquisition or merger will no longer have any reason to delay in replying to civil investigative demands; in fact, firms will have every reason to satisfy the enforcement agencies im order to trigger the start of the statutory waitimg period. ${ }^{190}$ The Commission and the Justice Department will have the option to request additional information during the waiting period, ${ }^{191}$ but the agencies will have inost of the necessary material at the beginning of the thirty-day period. Problems with the current reporting form may be resolved either by requests for additional information in order to clarify the initial report or by alterations in the reporting form to require more specific identification of industries and products. ${ }^{192}$ Consequently, the government will have a full and fair

Manual (Appendix B of 21972 Census of Manufacturers) (Executive Office of the President, Office of Management and Budget). Five-digit (SIC-based code) product class and seven-digit (SIC-based code) product: (1) "Numerical List of Manufactured Products," 1972 CENsus of Manufacturers (MC72-1.2) (New 1972 SIC basis); (2) "Industry Statistics," 21972 Census of MANufacturers. Five-digit (SIC-based code) product class: "Product Class Reference List," Instruction Manual for the ANNUAl SURvey of Manufacturers. Seven-digit (SIC-based code) product: "Product Reference Lists," Instruction Manual, Current Industrial RePORTs (monthly, quarterly or annual).

189. The codes, designed for census purposes, allow identification of products by their composition (metals, plastics, glass, etc.) and by their end use (parts for passenger cars, dinnerware, household appliances, etc.). Thus, products having inany components or multiple uses are difficult to classify. For example, spark plugs could be placed in a number of categories: 3694411 (automobile spark plugs); 3694431 (other type spark plugs); 3519915 (parts and accessories for internal combustion engines); 3714198 (parts for passenger cars); 35249311 (parts for lawnmowers); etc. While the Census Bureau could expect hittle dishonesty in the use of these codes, the FTC and the Justice Department may not be so fortunate, as reporting firms may wish to deemphasize anticompetitive impact. Also, the codes ignore producer interchangeability. Merging firms may be manufacturing products with vastly different end uses, but the cost of switching over to product lines having the same end use may be minimal. Again, anticonpetitive impact would not be revealed by the standard industrial classification codes.

190. See Umited States v. Ingersoll-Rand Co., 218 F. Supp. 530 (W.D. Pa.), affd, 320 F.2d 509 (3d Cir. 1963).

191. 15 U.S.C. \& 18a(e) (1976).

192. See 15 U.S.C. \& 18a(d)(2) (1976) (creating rule-making power); 15 U.S.C. \& 18a(e) (1976) (allowing requests for additional information and waiting period extension); 15 U.S.C. $\S 18 \mathrm{a}(\mathrm{j})$ 
opportunity to prepare an adequate showing. ${ }^{193}$

Given the current state of the law governing the preliminary injunction-its delicate balance between various standards on the required showing of likelihood of success-the question inevitably arises whether the reporting requirements will influence courts in either direction. It seems clear that any influence should be toward the reasonable probability standard. The government will now have access to all necessary data; it has a minimum of thirty days to prepare a showing of reasonable probability that the acquisition may tend to lessen competition. ${ }^{194}$ The reporting rules should have no effect on private antitrust suits, but the liberal showing of the Sonesta test seems inore readily applicable to private plaimtiffs in any case. The Sonesta test has led to hesitation or confusion when applied in government suits where presumptions of harm control. Furthermore, the substantial questions test has proved particularly attractive when the issues are too complex to be handled in depth in a preliminary proceeding. The notification requirements, however, should enable the government to show a reasonable probability of success despite complicated issues and despite the preliminary nature of the proceeding. If the governinent cannot inake a showing of a likelihood of success on the merits, it is doubtful that an injunction should issue.

The legislative history of the Antitrust Improvenents Act states that the reporting requirements were not intended to change the substantive rules governing preliminary injunctions. ${ }^{195}$ In view of the unstable state of the law, however, no such change is necessary. A court may simply choose to follow one line of cases-that requiring a reasonable probability of success-rather than another line applying Sonesta's dual standard. In fact, the legislative history assumes that the reasonable probability standard prevails in all circuits. ${ }^{196}$ Although

(1976) (requiring FTC to report to Congress and to include recommendations for revision of section).

193. See note 41 supra. See Senate Hearings, pt. III, at 72 (statenent of Eleanor Fox) ("Having this information, the Government will be well situated to get preliminary relief where it is reasonably likely to prevail. When the Government's case is so thin that it is not likely to prevail, we [the ABA's Antitrust Section] believe inerging companies should liave the right to consummate the transactions").

194. HOUSE REPORT 7 ("Thus, both Congress and the courts have repeatedly empluasized that section 7 is an 'incipiency' statute: $\mathrm{It}$ is intended to halt monopolies and restraints of trade in their initial stages, before they ripen into full-scale Sherman Act violations. . . . [T]he government carries the burden of proof in preinerger injunction proceedings, and must demonstrate a 'reasonable probability that it will prevail on the merits of its Clayton Act challenge' " (footnote omitted)).

195. HOUSE REPORT 8.

196. E.g., id. 7; Senate Hearings, pt. II, at 1001 (letter froin Thomas Kauper to Senator Hart). 
the House Report characterizes the standard as steep because the test is frequently the same as that required for final relief, ${ }^{197}$ Congress close not to alter the test-as was certainly within its power-but to seek a less drastic solution. Whether the statute will have any impact on the current liberal trend is yet to be determined, but any reaction by the courts should be in the direction of retreat ratler than further liberalization.

\section{The Impact of the New Report-And-Wait Rules: The GOVERNMENT'S SHOWING ON THE EQUITIES}

Courts weighing the equities often turn to expressions of public policy contained in statutes or legislative history im order to resolve difficulties in ineasuring the public interest; furthermore, the courts taking this approach have usually found the public interest to be paramount. ${ }^{198}$ A great deal of legislative history hes behind the new statute, ${ }^{199}$ and it is quite likely that courts will look to congressional statements on the purpose and intent of the Act. Again, no change in substantive law is necessary. A court need only empliasize legislative concern with the agencies' failures to prevent anticompetitive inergers and with the inadequacy of divestiture in order to tip the equities decidedly in the government's favor. ${ }^{200}$

A superficial examination of the legislative history may well convince a court that the public interest is of sucl magnitude as to outweigh any private harm. Antitrust laws have long been held to protect an especially important public interest; the prevailing attitude is that "democracy can be preserved only by dispersing and decentralizing economic and financial power."201 Congress lias been particularly solicitous-if not always perfectly rational - in guarding against the adverse effects of anticoinpetitive behavior. ${ }^{202}$ In addition, Congress has expressed dissatisfaction with the enforcement agencies' record in preventing consumination of questionable mergers: "[T]he weight of the burden of proof [in antimerger cases], together with the present lack

197. HOUSE REPORT 7-8.

198. E.g., FTC v. Food Town Stores, Inc., 539 F.2d 1339 (4th Cir. 1976), vacated as moot, 547 F.2d 247 (4th Cir. 1977); FTC v. Lancaster Colony Corp., 434 F. Supp. 1088 (S.D.N.Y. 1977).

199. Senate Hearings; House RePORT; 122 CoNG. REC. H10,293-94 (daily ed. Sept. 16, 1976) (remarks of Rep. Rodino); id. S15,416-20 (daily ed. Sept. 8, 1976) (Senator Hart's post-debate "Additional Statement"; remarks of Sen. Percy); id. S14,889 (daily ed. Aug. 27, 1976) (remarks of Sen. Hart).

200. E.g., FTC v. Lancaster Colony Corp., 434 F. Supp. 1088 (S.D.N.Y. 1977).

201. House RePORT 7.

202. Handler, Antitrust-Myth and Reality in an Inflationary Era, 50 N.Y.U.L. REv. 211, 217 23 (1975). 
of any premerger notification and waitmg requirements, has meant that many large and illegal mergers have been successfully consummated in recent years, before the government had any realistic chance to challenge them."203 After consummation of the merger, divestiture has proved inadequate to restore the competitive environment; ${ }^{204}$ the public interest can only be protected by more effective preliminary relief.

Thomas Kauper, ${ }^{205}$ in enumerating the benefits of the new reportand-wait rules, pointed out that preliminary relief has been far more effective than divestiture. ${ }^{206}$ Joseph Brodley ${ }^{207}$ elaborated on this issue: "The only significant exception to this bleak remedial picture oceurs im those relatively few cases in which the government has been able to obtain advance injunctive relief staymg the merger pending the resolution of the cases." 208 The House Report accepted this analysis, citing United States v. El Paso Natural Gas Co ${ }^{209}$ and United States v. Papercraft Corp. ${ }^{210}$ as exainples of divestiture's failure to protect the public interest and United States v. Amax, Inc., ${ }^{211}$ where the firms voluntarily delayed the merger pending final decision, as a model of success. ${ }^{212}$

A court considering the history of the legislation might be influenced to grant a preliminary injunction on the ground that the public will suffer serious injury in the interim prior to final decision. Further, once the equities tip decisively in favor of the government, the lesser standard of Sonesta is applicable. Thus, the government's burden is lightened on botl points. The courts, reluctant to gamble that a divestible entity will be in existence after final disposition, may move further

203. HOUSE REPORT 8.

204. See notes $4,42-43$ supra.

205. Assistant Attorney General, Antitrust Division, U.S. Department of Justice.

206. Senate Hearings, pt. I, at 96. There are a number of benefits associated with the new notification statute: first, facilitating preliminary relief; second, notice of challenge to merging companies prior to consummation; third, prevention of midnight mergers; and finally, early compilation of basic data necessary for effective enforcement. Id. Kauper also enumerated six reasons for the imadequacy of divestiture: first, the assets of the firms have become hopelessly entangled by the time a divestiture order is entered; second, the personnel of the acquired firm may have undergone substantial turnover and those employees who have remained may have changed loyalties; third, the goodwill of the acquired firm may have shifted to the acquiring firm; fourth, divestiture is a slow process, usually taking years to complete; fifth, an interim change im market conditions often makes restoration of the premerger status quo inpossible-a suitable buyer may or may not be found; and finally, firms often deliberately delay divestiture, stalling so as to reap all possible profits from the merger. Id.

207. Professor of Law, Indiana University, Bloomington, Indiana.

208. Senate Hearings, pt. I, at 506.

209. 376 U.S. 651 (1964).

210. 393 F. Supp. 408 (W.D. Pa. 1975).

211. 402 F. Supp. 956 (D. Conn. 1975).

212. HOUSE REPORT 10. 
toward a pro forma approach to the preliminary injunction. ${ }^{213}$

The courts, however, inust be cautious in adopting this type of approach, in view of legislative history indicating that Congress wished the courts to maintain broad discretion in issuing preliminary injunctions. As noted earlier, Congress rejected the automatic stay provision in the origimal Senate bill. ${ }^{214}$ As Senator Percy stated in debate, "[A] number of unergers . . . which are clearly in the public interest . . . would be prevented or discouraged. In some cases years of hard work in planning a inerger will have been for naught. Ineffectual or incompetent manageinent . . . may be kept in power at the expense of public shareholders, consumers and the Government."215 Percy's statement reflects congressional concern with private, corporate injury and with the fundamental public interest in preserving hquidity in the assets inarket. In fact, Congress rejected not only the automatic stay but also an alternative proposal which would have merely shifted the burden of proof to the defendants. ${ }^{216}$ The legislature clearly realized that "[in]aintenance of a free inarket for capital assets is essential in the long run to coinbat inflation; to that end, it is important that more efficient companies be permitted to acquire the less efficient."217 The Second Circuit has agreed in principle that the courts must avoid any broad interpretation of Clayton Act section 7 that would "damage seriously the market for capital assets" or "interfere materially with mergers that are procompetitive."218

Business interests have been even more forceful and eloquent in justifying merger activity. A letter from the Securities Industry Association to Senator Hart offers an excellent summary of the benefits of procoinpetitive mergers:

The free flow of capital permits companies to grow and prosper and to provide goods, services, and jobs. Mergers and acquisitions ... . play an important role in this capital allocation process. Such activities strengthen competition and competitors. They provide a mecha1ism whereby participants who choose to leave the market can do so, while new competitors can enter. Busmess founders can reap the re-

213. See Note, supra note 18 , at 170 .

214. See text accompanying notes $46-56$ supra.

215. ConG. REC., supra note 52.

216. Senate Hearings, pt. 111, at 71 (statement of Eleanor Fox) ("Senator Scott and Hart have proposed an amendment [to section 501(d) of S. 1284] . . . The preliminary injunction would issue unless defendants show that the Government does not have a reasonable probability of success on the merits or that defendants will be irreparably injured by loss other than loss of benefits of the transaction. The burden on defendants would be a hard one indeed . ..."). Of course, the compromise bill finally enacted contained no such provision. HOUSE REPORT 8.

217. Senate Hearings, pt. I, at 530 (statement of Robert Longman).

218. Missouri Portland Cement Co. v. Cargill, Inc., 498 F.2d 851, 854 (2d Cir.), cert. denied, 419 U.S. 883 (1974). 
wards of their development efforts. Unsuccessful competitors can limit their losses. Diversified companies can release inefficient or unsuitable segments of their enterprises. New groups can assume leadership roles of public companies (or at least keep current inanageinent on its toes) by the tender offer inechamsm, thus assuring innovation and change. 219

Corporate representatives emphasized the point that "the great majority of merger-type transactions are economically healthy" 220 and that "government agencies only attack mergers in a small number of cases."221 While the corporate testimony is clearly in the nature of a lobbying effort, the risk of discouraging lawful mergers cannot be discounted; the courts must avoid too liberal an approach im issuing preliminary injunctions against mergers.

In weighing the equities, the courts must consider not only private harm, but also two countervailing components of the public imterest. The courts must guard agamst too heavy a concentration of market power. As a House task force concluded: "Increasing sectors of our economy have becoine alarmingly vulnerable to monopoly and effective oligopoly . . . . We have witnessed the systematic development of planned obsolescence in a variety of products and a growing tendency to reduce output rather than prices."222 Congress has demanded that courts prevent the effective repeal of the "fundamental laws of the competitive inarketplace."223 On the other hand, courts must weigh the public interest in a free market for capital assets, where entry and exit from industries are relatively free from government regimentation. If

219. Senate Hearings, pt. II, at 1033.

There is a serious question whether free enterprise can survive this kind of government dictation of the size, shape, structure, and mode of operation of the economy. Pricing pohicies, marketing procedures, and capital arrangements and rearrangements are the essence of our system. When these matters are controlled by the decisions of administrative agencies ...., rather than by men staking their fortunes on their ability to serve consumers, the result is the corporative state. Antitrust principles are now being pursued to the bitter end. Had they been pushed so far at the start, the economy would have been frozen in a relatively primitive cast .... and beyond much doubt, nowhere near the technological progress, the wages, or the standard of hiving that now prevails.

Petro, The Growing Threat of Antitrust, ForTune, Nov. 1962, at 128. See Brown Shoe Co. v. United States, 370 U.S. 294, 319-20 (1962) ("Congress recognized the stimulation to competition that might flow from particular mergers. ... . Taken as a whole, the legislative history illuminates congressional concern with the protection of competition, not competitors, and its desire to restrain mergers only to the extent that such combimations may tend to lessen competition." (emphasis im origimal)).

220. Senate Hearings, pt. I, at 165 (statement of J. Randolph Wilson on behalf of U.S. Chamber of Commerce).

221. Id. 529.

222. Handler, supra note 202, at 218 n.33 (quoting H.R. TASK FORCE REP., "To Revive the Economy: A Congressional Program of Action," reprinted in DAILY LABOR REP. No. 8 (BNA), at Y-1, Y-4 (Jan. 13, 1975)).

223. Id. 
Adam Smith's "mvisible hand" is to guide the American marketplace, ${ }^{224}$ it cannot be manacled by protracted delay and unnecessary interference from the government agencies.

The legislative history of the report-and-wait statute illustrates the conflict between these two components of public interest. Congress carefully balanced these countervailing considerations and concluded that the courts should be allowed to retain broad discretion in issuing preliminary injunctions. Courts weighing the equities should be as careful as Congress was in drafting the legisation. The federal courts should be aware of the need for inergers and acquisitions to move freely and quickly; they should be sensitive to the likelihood that preliminary rehef will create an insuperable bar to a proposed inerger. Congress rejected the autoinatic stay and a shift in the burden of proof; the courts should avoid a pro forma approach or a burdensoine presumption in the government's favor.

\section{CONCLUSION}

Federal courts should take a cautious approach in issuing preliminary injunctions against mergers under the expeditcd procedure of the new report-and-wait statute. The Sonesta approach inay be useful in private litigation, but its appearance in government suits has led to confusion regarding the standards to be applied in granting or refusing injunctive relief. Contemporary developments on the equities make Sonesta inappropriate im government suits. The circuit courts nay retreat to the reasonable probability standard, secure in the knowledge that the government will have early access to all information necessary to show a likelihood of success. The Fourth Circuit's refusal to weigh private injury nnder section 13(b) should be reexamined in hight of the legislative history of the Antitrust Improvements Act of 1976, since

224. 1 A. Smith, AN Inquiry into the Nature and Causes of the Wealth of Nations 456 (Oxford 1976) (1st ed. London 1776). Smith's views on government regulation may be antiquated:

The statesman, who should attempt to direct private people in what manner they ought to employ their capitals, would not only load himself with a most unnecessary attention, but assume an authority which could safely be trusted, not only to no single person, but to no council or senate whatever, and which would nowhere be so dangerous as in the hands of a man who had folly and presumption enough to fancy himself fit to exercise it.

Id. The wisdoin in his metaphor, however, endures:

[E]very individual necessarily labours to render the annual revenue of the society as great as he can. He generally, indeed, neither intends to promote the publick interest, nor knows how much he is promoting it. ... [H] intends only his own gam, and he is in this, as in many other cases, led by an invisible hand to promote an end which was no part of his intention. . . By pursuing his own interest he frequently promotes that of society more effectually than when he really intends to promote it.

Id. (emphasis added). 
Congress did express concern for private hardships. Courts which have taken a similar approach should be more hesitant to conclude that the public interest always outweighs private harm; Congress did not intend that the Commission and the Antitrust Division fashion a model economy based on the agencies' conception of the public interest. Congress apparently concluded that preliminary injunctive relief is still a drastic remedy, and the courts should follow the pohicy ultimately adopted by the legislature after years of careful consideration and comproumse: a conservative approach to the use of the preliminary injunction in antitrust cases.

Rudolf W. Beuttenmuller 